\title{
The miRacle in Pancreatic Cancer by miRNAs: Tiny Angels or Devils in Disease Progression
}

\author{
Zuhair Hawa 1,t,\#, Inamul Haque 1,2,*,†, Arnab Ghosh ${ }^{1,2}$, Snigdha Banerjee ${ }^{1,2, *}$, \\ LaCoiya Harris ${ }^{1}$ and Sushanta K. Banerjee ${ }^{1,2,3,4, *}$ \\ 1 Cancer Research Unit, VA Medical Center, Kansas City, MO 64128, USA; zzhawa@hotmail.com (Z.H.); \\ aghosh2@kumc.edu (A.G.); lacoiya.harris@va.gov (L.H.) \\ 2 Division of Oncology, Department of Internal Medicine, University of Kansas Medical Center, Kansas City, \\ KS 66205, USA \\ 3 Department of Anatomy and Cell Biology, University of Kansas Medical Center, Kansas City, KS 66205, USA \\ 4 Department of Pathology, University of Kansas Medical Center, Kansas City, KS 66205, USA \\ * Correspondence: ihaque@kumc.edu (I.H.); sbanerjee@kumc.edu (S.B.); sbanerjee2@kumc.edu (S.K.B.); \\ Tel.: +1-816-861-4700 (ext. 57057) (S.K.B.); Fax: +1-816-922-3320 (S.K.B.) \\ + These authors contributed equally to this work. \\ \# High school student in Summer Research Project.
}

Academic Editor: Y-h. Taguchi

Received: 25 March 2016; Accepted: 19 May 2016; Published: 26 May 2016

\begin{abstract}
Pancreatic ductal adenocarcinoma (PDAC) is an aggressive malignancy with increasing incidence and high mortality. Surgical resection is the only potentially curative treatment of patients with PDAC. Because of the late presentation of the disease, about 20 percent of patients are candidates for this treatment. The average survival of resected patients is between 12 and 20 months, with a high probability of relapse. Standard chemo and radiation therapies do not offer significant improvement of the survival of these patients. Furthermore, novel treatment options aimed at targeting oncogenes or growth factors in pancreatic cancer have proved unsuccessful. Thereby, identifying new biomarkers that can detect early stages of this disease is of critical importance. Among these biomarkers, microRNAs (miRNAs) have supplied a profitable recourse and become an attractive focus of research in PDAC. MiRNAs regulate many genes involved in the development of PDAC through mRNA degradation or translation inhibition. The possibility of intervention in the molecular mechanisms of miRNAs regulation could begin a new generation of PDAC therapies. This review summarizes the reports describing miRNAs involvement in cellular processes involving pancreatic carcinogenesis and their utility in diagnosis, survival and therapeutic potential in pancreatic cancer.
\end{abstract}

Keywords: microRNA; pancreatic cancer; OncomiR; tumor suppressor; PanIN; cancer stem cells; epithelial to mesenchymal transition; TS-miR

\section{Introduction}

Pancreatic ductal adenocarcinoma (PDAC) is an aggressive malignancy with increasing incidence and high mortality. PDAC is among the ten most commonly diagnosed cancers and is the fourth leading cause of cancer related death in the United States with a five-year survival rate of approximately 3-6 percent and a median of survival rate of 2-8 months [1]. Although the standard of care in advanced pancreatic cancer is improved through targeted therapies and personalized medicines [2,3], prognosis and treatment of PDAC still remains unsatisfactory. Due to the impalpable, asymptomatic and invasive nature of the disease, diagnosis of PDAC at an early stage is impossible. PDAC typically presents with metastasis at the time of diagnosis. Unfortunately, no curative treatment is available for advanced stages of the disease. 
Surgical resection is the only potentially curative treatment of patients with PDAC, followed by chemotherapy. However, because of the late presentation of the disease, only 15 to 20 percent of patients can go in for surgery. The patients who undergo the procedure are likely to relapse, but the average survival of resected patients is between 12 to 20 months [4]. Standard chemo and radiation therapies do not offer significant improvement of survival for these patients. New treatments targeting known oncogenes, or growth factors, in pancreatic cancer such as K-Ras, vascular endothelial growth factor (VEGF) and epidermal growth factor (EGF)/epidermal growth factor receptor (EGFR) have mostly failed and do not provide survival benefits $[5,6]$. Therefore, it is important to identify biomarkers that can detect early stages of this devastating disease with high sensitivity and specificity. Among these biomarkers, microRNAs (miRNAs) have supplied a profitable recourse and become an attractive focus of research.

The microRNAs (miRNAs) are non-coding, small RNA molecules about 19-22 nucleotides in length. MiRNAs are post-transcriptional regulators that bind to the $3^{\prime}$-untranslated region ( $3^{\prime}$-UTR) on target mRNAs, usually resulting in translational repression and gene silencing [7]. Many miRNAs have been shown to play a vital role in either progression or suppression of cancer [8-11]. Recent studies have shown that miRNAs are key regulators of PDAC initiation and progression, and these events could be mediated by modulating proliferation, apoptosis, metastasis, angiogenesis, chemosensitivity, stemness and radiosensitivity [2,12-19]. The importance of miRNAs in PDAC has been highlighted by numerous studies that have shown the abnormal expression of different miRNAs can lead to chronic pancreatitis, different grades of pancreatic intraepithelial neoplastic (PanIN) and PDAC [20-24]. All these studies provide significant insight into altered cellular features such as growth, invasive and metastatic behavior of PDAC cells and have established a close relationship between miRNAs and PDAC progression. Recent data revealed that a comprehensive knowledge of the atypical expression of these miRNAs and reestablishment of their normal expression patterns could produce a favorable therapeutic method and help establish targeted approaches for the preclusion of this disease. These aberrantly expressed miRNAs may function either as oncogenic miRNAs (oncomiRs) (Table 1) or tumor suppressor miRNAs (TSmiRs) (Table 2), and they appear to play important roles with respect to the initiation, progression and metastatic growth of distal organs in PDAC. Thus, the possibility of intervention in the molecular mechanisms of miRNA regulation could begin a new generation of pancreatic cancer therapies. This review summarizes the recent reports describing miRNAs' involvement in cellular processes involving pancreatic carcinogenesis and their utility in diagnosis, survival prognosis and therapy.

Table 1. Different oncogenic miRNAs in pancreatic cancer.

\begin{tabular}{|c|c|c|c|c|c|}
\hline MiRNA & Type & Regulation & Location & Targets & References \\
\hline$m i R-21$ & Oncogenic & Up & $17 q 23.2$ & PTEN, PDCD4, TIMP3 & {$[9,25-27]$} \\
\hline$m i R-221$ & Oncogenic & Up & Xp11.3 & TRPS1, p27kip1 & {$[28-31]$} \\
\hline miR-155 & Oncogenic & $\mathrm{Up}$ & $21 \mathrm{q} 21$ & TP53INP1, SOCS1 & {$[24,32-34]$} \\
\hline$m i R-10 b$ & Oncogenic & Up & $2 q 31.1$ & TIP30 & {$[35-37]$} \\
\hline$m i R-208$ & Oncogenic & Up & $14 \mathrm{q} 11$ & E-cadherin & {$[38,39]$} \\
\hline miR-192 & Oncogenic & Up & 11q13.1 & $\begin{array}{c}\text { Rb1, p27 }{ }^{\mathrm{Kip} 1}, \mathrm{p} 21^{\mathrm{Cip} 1}, \\
\text { CyclinD1/2, SKP-2,CDK4, CDC2 }\end{array}$ & {$[40,41]$} \\
\hline$m i R-425-5 p$ & Oncogenic & Up & $3 \mathrm{p} 21.31$ & SOCS6 & [42] \\
\hline$m i R-483-3 p$ & Oncogenic & Up & $11 \mathrm{p} 15.5$ & DPC4/Smad4 & [43] \\
\hline$m i R-421$ & Oncogenic & Up & Xq13.2 & DPC4/Smad4 & [44] \\
\hline miR-132 & Oncogenic & Up & $17 \mathrm{p} 13$ & $\mathrm{Rb} 1$ & [45] \\
\hline$m i R-212$ & Oncogenic & Up & 17 p13 & $\mathrm{Rb} 1$ & [45] \\
\hline$m i R-191$ & Oncogenic & Up & $3 p 21.31$ & UPS10 & [46] \\
\hline$m i R-212$ & Oncogenic & Up & $17 \mathrm{p} 13.3$ & Patched-1 & [47] \\
\hline
\end{tabular}


Table 2. Different Tumor suppressor miRNAs in pancreatic cancer.

\begin{tabular}{|c|c|c|c|c|c|}
\hline MiRNA & Type & Regulation & Location & Targets & References \\
\hline $\begin{array}{l}\text { miR-200 } \\
\text { Family }\end{array}$ & $\begin{array}{c}\text { Tumor } \\
\text { Suppressor }\end{array}$ & Down & $1 \mathrm{p} 36,12 \mathrm{p} 12$ & $\begin{array}{l}\text { VEGF-A, FLT1/VEGFR1 } \\
\text { KDR/VEGFR2 }\end{array}$ & [48-54] \\
\hline$m i R-34 a$ & $\begin{array}{c}\text { Tumor } \\
\text { Suppressor }\end{array}$ & Down & $1 \mathrm{p} 36.22$ & $\begin{array}{l}\text { Notch1/2, Bcl-2, Cyclin D1, Survivin, } \\
\text { SIRT1,VEGF, CDK4/6, p27 KIP1 }\end{array}$ & [55-59] \\
\hline$m i R-146 a$ & $\begin{array}{l}\text { Tumor } \\
\text { Suppressor }\end{array}$ & Down & $5 q 33.3$ & EGFR, IRAK-1, MTA-2 & [60-62] \\
\hline $\operatorname{miR}-124$ & $\begin{array}{l}\text { Tumor } \\
\text { Suppressor }\end{array}$ & Down & $\begin{array}{l}8 \mathrm{p} 23.1,8 \mathrm{q} 12.3 \\
20 \mathrm{q} 13.33\end{array}$ & $\begin{array}{l}\text { Rac1, ITGB1, EZH2, ROCK2, uPA, } \\
\text { Lhx2 }\end{array}$ & [63-67] \\
\hline miR-203 & $\begin{array}{l}\text { Tumor } \\
\text { Suppressor }\end{array}$ & Down & $14 q 32-33$ & Survivin, Caveolin-1 & {$[68,69]$} \\
\hline $\operatorname{miR}-615-5 p$ & $\begin{array}{c}\text { Tumor } \\
\text { Suppressor }\end{array}$ & Down & $12 q 13.13$ & Akt2, IGF2, JUNB & [70-73] \\
\hline$m i R-206$ & $\begin{array}{l}\text { Tumor } \\
\text { suppressor }\end{array}$ & Down & $6 \mathrm{p} 12.2$ & K-Ras, ANXA2 & [74] \\
\hline$m i R-96$ & $\begin{array}{l}\text { Tumor } \\
\text { Suppressor }\end{array}$ & Down & $7 q 32.2$ & NUAK1, Akt, HERG1, K-Ras & [75-77] \\
\hline $\operatorname{miR}-410$ & $\begin{array}{c}\text { Tumor } \\
\text { Suppressor }\end{array}$ & Down & $14 q 32.31$ & AGTR1 & [78] \\
\hline $\operatorname{miR}-3548$ & $\begin{array}{c}\text { Tumor } \\
\text { Suppressor }\end{array}$ & Down & - & Gli-1 & [79] \\
\hline
\end{tabular}

\section{Biosynthesis of miRNAs}

The biosynthesis of miRNAs, or the process of making miRNAs, is a tightly regulated multistep process that takes place both in the nucleus and cytoplasm [80]. In the nucleus, the miRNA gene is first transcribed by RNA polymerase II or III to produce a long primary miRNA (pri-miRNA) characterized by hairpin structure, which is $5^{\prime}$-capped and $3^{\prime}$-polyadenylated [81]. The pri-miRNA is cropped by the Drosha/GDCR8 complex into a 60-100 nucleotide hairpin structure termed the precursor-miRNA (pre-miRNA) [82]. These pre-miRNA molecules are then transported to the cytoplasm through the interaction with nuclear transport receptor Exportin-5 and nuclear protein Ran-GTP where it is further processed by DICER1. A second RNase III endonuclease, together with its catalytic partner, TAR-binding protein (TRBP), cleaves the pre-miRNA into a double stranded $\sim 22$ nucleotide product comprised of the mature miRNA (guide strand) and the miRNA* (passenger strand). The $\mathrm{miR} / \mathrm{miR}$ * duplex is then loaded into a multicomponent complex, the RNA-induced silencing complex (RISC), constituted of at least TRBP, DICER1 and one Argonaute-2 (Ago2) $[7,83]$. The miR* passenger strand is cleaved by Ago2 while the miR serves as a guide for target recognition to either degrade the mRNA or cause translational suppression, depending on the level of complementarity between the miRNA and its target mRNA (Figure 1). 


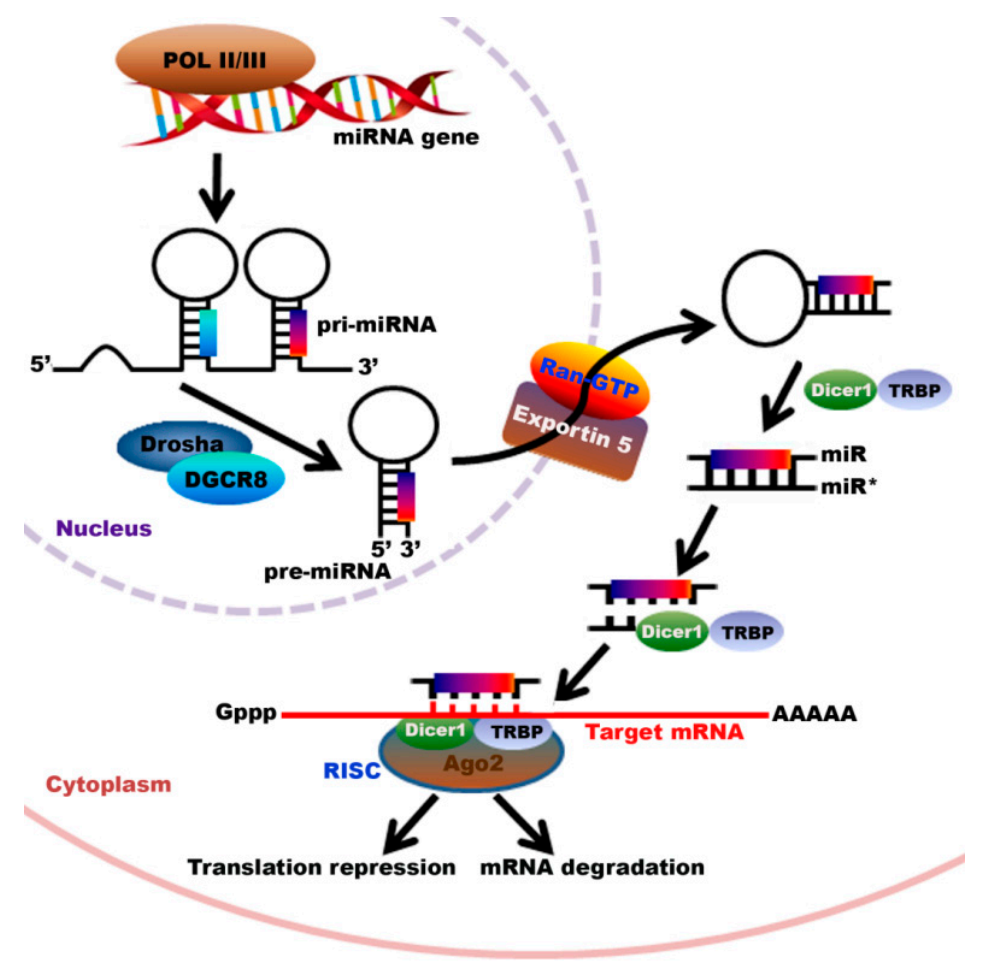

Figure 1. Biosynthesis of miRNAs. The miRNA is first transcribed within the nucleus by RNA polymerase II and II to generate a long primary miRNA (pri-miRNA), which is cropped by the Drosha/GDCR8 complex into precursor-miRNAs (pre-miRNAs). These pre-miRNAs are then transported to the cytoplasm through the interaction with nuclear transport receptor Exportin-5 and nuclear protein Ran-GTP. Once in the cytoplasm, the pre-miRNA is further processed by DICER1 and TAR-binding protein (TRBP) into a double stranded $\sim 22$ nucleotide product comprised of the mature miRNA guide strand and the miRNA* passenger strand. The miR* passenger strand is cleaved by Ago 2 and the mature miRNA is then incorporated into the RNA-induced silencing complex (RISC) to target the $3^{\prime}$-untranslated region of the target mRNA.

\section{OncomiRs in Pancreatic Cancer}

The oncomiRs are the cluster of microRNAs known to contribute to the tumorigenic process through the regulation of genes associated with cell growth and differentiation. Multiple oncomiRs have been identified thus far and were found to be actively involved with pancreatic cancer development. Six of them are described below:

\subsection{MicroRNA 21 (miR-21)}

MiR-21 is located in the $3^{\prime}$-UTR of VMP1 (vacuole membrane protein 1) gene, also known as transmembrane protein 49 (TMEM49), at chromosome 17q23.2 [9]. Multiple studies have suggested a relationship between aberrant expressions of miRNA and human pancreatic cancer [84]. MiR-21 is one of the most studied miRNAs in cancer, and its overexpression is associated with increased proliferation, invasive phenotypes and resistance to chemotherapeutic drug gemcitabine (Gemzar), creating the worst overall survival probability in pancreatic cancer patients [85-89]. The overexpression of miR-21 is associated with human PanIN grade, with peak production occurring in PanIN-2/3 lesions and regulated by K-Ras ${ }^{\text {G12D }}$ and EGFR in PDAC-derived cell lines [90]. MiR-21 binds with the mRNA of phosphatase and tensin homolog (PTEN), a known tumor suppressor, and represses its translation, thereby reducing its tumor suppressive action on cell proliferation of pancreatic tumor cells [25,91,92]. Increased miR-21 expression has been associated with activation of PI3K/Akt/mTOR pathway, which promotes cell survival, proliferation and progression in pancreatic cancer cells $[26,93]$. 
The invasive phenotypes of pancreatic cancer cells are promoted by miR21 via indirect regulation of matrix metalloproteinases (MMPs), as well VEGF [26,87]. A recent study showed that miR-21 is induced by hypoxia in pancreatic cancer via hypoxia inducible factor- $1 \alpha(\mathrm{HIF}-1 \alpha)$ upregulation and allows cells to avoid apoptosis in a hypoxic microenvironment [94]. Thereby, miR-21 overexpression in pancreatic cancer cells is an impelling cause of cancer progression and suggested to be a potential prognostic biomarker of the patients with PDAC.

\subsection{MicroRNA 221 (miR-221)}

OncomiR miR-221 is located $700 \mathrm{bp}$ from miR-222 on the chromosome Xp11.3 [30]. Several studies have reported that miR-221 is upregulated in human primary pancreatic cancer tissues or human pancreatic cancer cell lines compared to normal pancreas tissues and pancreatic duct epithelial cells, respectively $[29,84,95-97]$. Overexpression of miR-221 has also been reported in the mouse pancreas with PanIN lesion [95]. MiR-221 promotes cell proliferation via binding with $3^{\prime}$-UTR of p27kip1, a tumor suppressor and a member of the Cip/Kip family of cyclin-dependent kinase (CDK) inhibitors [28,31]. MiR-221 is vital for the platelet-derived growth factor (PDGF)-mediated epithelial-mesenchymal transition (EMT) phenotype, migration and growth of pancreatic cancer cells by down-regulating tricho-rhino phalangeal syndrome type 1 (TRPS1) and p27 [31]. Moreover, the pancreatic cancer patients with high miR-221 expression had comparatively shorter survival than those with lower expression, suggesting that miR-221 could be a prognostic factor for worst survival of patients [29].

\subsection{MicroRNA-155 (miR-155)}

The miR-155 locus is located in chromosome 21q21 within a region known as the B-cell integration cluster (BIC) gene [24]. MiR-155 is overexpressed in a variety of solid, human tumors such as breast cancer [98-101], lung cancer [102-104], thyroid tumor [105,106] and prostate cancer [107], as well as pancreatic cancer $[34,85,108-110]$. These studies illustrate that miR-155 plays a crucial role in tumor development, diagnosis and prognosis. Pancreatic cancer cell migration, invasion and metastasis can be regulated by miR-155 via targeting 53-induced nuclear protein 1 (TP53INP1) $[33,34]$ or by regulating the suppressor of cytokine signaling 1 (SOCS1) through the STAT3 signaling pathway $[33,34,98,111]$. Moreover, miR-155 negatively regulates Mut L homolog 1 (MLH1), a prognostic determinant in several cancers, including pancreatic cancer, and expressions were revealed in the K-Ras ${ }^{\mathrm{G} 12 \mathrm{D}}$ transgenic mouse model of PC [112-117]. Mechanistically, K-Ras activation upregulated miR-155 expression through MAPK and NF- $\mathrm{kB}$ pathway, and miR-155 promoted reactive oxygen species (ROS) stress via inhibiting FOXO-3a expression in pancreatic cancer [110]. Overexpression of miR-155 is correlated with poor prognoses of pancreatic cancer [113]. Collectively, these studies demonstrate that miR-155 is an important oncomiR in the development as well as aggressive behavior of pancreatic cancer.

\subsection{MicroRNA 10b (miR-10b)}

MiR-10b is located between HOXD4 and HOXD8 on chromosome 2q31.1 and is particularly associated with metastatic behaviors of cancer cells [35]. MiR-10b was first identified to promote tumor metastasis in breast cancer [36], which is regulated by a matricellular protein CCN5 via HIF- $\alpha$-TWIST signaling pathway [118]. Subsequently, involvement of miR10b with tumor invasive potential in nasopharyngeal carcinoma [119,120], glioma [121,122], acute myeloid leukemia [123], esophageal cancer [124], colon cancer [125], neurofibromatosis type 1 [126] and pancreatic cancer [85,89,127,128] has been documented. In pancreatic cancer, miR-10b is overexpressed in both pancreatic cancer cell lines and tissue samples [127], and is associated with invasive behavior and poor prognosis of pancreatic cancer. MiR-10b decreased the expression of homeobox D10 (HOXD10), a member of the HOX genes family, resulting in increased expression of RhoC, a HOXD10 target and a metastasis promoter [36]. Moreover, studies from two different laboratories show an association between the overexpression of miR-10b and urokinase-type plasminogen activator receptor (uPAR), a 
downstream target of HOXD10 [122,129]. Recently, Korc and coworkers reported that downregulating Tat-interacting protein 30 (TIP30) and upregulating EGFR by miR-10b microRNA caused EGF-mediated invasion in pancreatic cancer [37]. Collectively, miR-10b overexpression could be associated with progression of disease and poor prognosis.

\subsection{MicroRNA-208 (miR-208)}

MiR-208 is located on chromosome $14 \mathrm{q} 11$ and is highly expressed in various cancers like esophageal squamous cell carcinoma [39], prostate cancer [130] and hepatocellular carcinoma [131]. Although little information available regarding miR-208 expression and its role as an oncomiR in pancreatic cancer, a recent finding suggests that miR-208 regulates EMT by down-regulating E-cadherin and activating AKT/GSK-3 $\beta$ /snail signaling pathway, thereby promoting tumor cell invasion and metastasis of pancreatic cancer cells [38].

\subsection{Additional OncomiRs in Pancreatic Cancer}

Other oncomiRs contributing to the development and progression of pancreatic cancer include miR-192, which facilitates progression from G0/G1 to $S$ phase by regulating the expression of genes involved in cell cycle control [41,132]. MiR-192 overexpression diminished the expression of p21 ${ }^{\text {Cip1 }}$, p27 ${ }^{\mathrm{Kip} 1}$, p107, p130 and retinoblastoma-1 tumor suppressor protein (Rb1) and increased the expression of cyclin D1, cyclin D2, CDK4, CDC2, and SKP-2 in both pancreatic cancer tissues and cell lines [41,132]. The growth-promoting effect of miR-192 was also documented in colony formation assay and in Panc-1 xenograft tumor model [41]. In addition, miR-192 overexpression attenuated cell apoptosis and stimulated cell proliferation and migration in pancreatic cancer cells [41,132]. In contrast, several studies indicate that miR-192 acts as a tumor suppressor as it inhibits cancer cell proliferation through induction of p53-dependent cell cycle arrest at both the G1 and G2 phases in colon cancer [133] and through targeting $\mathrm{Rb} 1$ in lung cancer [40]. OncomiR, miR-424-5p was also found to be overexpressed in pancreatic cancer [42]. This miRNA increased the ability of cells to proliferate, migrate, invade and inhibit cell apoptosis through downregulation of suppressor of cytokine signaling 6 (SOCS6) protein, which leads to elevated ERK1/2 signaling pathway activity [42]. Hao et al., using a miRNA-array differential analysis, reported that miR-483-3p expression was greater in pancreatic cancer tissue compared to adjacent normal tissues [43]. MiR-483-3p overexpression in pancreatic cancer cell lines significantly represses DPC4/Smad4 protein levels and simultaneously promotes cell proliferation and colony formation in vitro. In another study, Hao et al. found that miR-421 was highly upregulated in specimens of human pancreatic cancer, and it promotes cell proliferation and colony formation by suppressing DPC4/Smad4, a tumor suppressor in pancreatic cancer [44]. Park and colleagues reported that two miRNAs located on chromosome 17p13, miR-132 and miR-212 are highly expressed in PDAC tissues and downregulate the tumor suppressor Rb1, thereby increasing cell proliferation [92]. MiR-191 has been reported to promote pancreatic cancer through targeting UPS10, which suppresses the proliferation and growth of cancer cells by stabilizing the p53 protein [46]. Recently, another miRNA, miR-212, has been established as an oncomiR in PDAC by Ma et al. [47]. The researchers reported that this microRNA promotes pancreatic cancer cell proliferation, migration and invasion by targeting the hedgehog signaling pathway receptor patched-1.

\section{Tumor Suppressor miRNAs (TSmiRs) in Pancreatic Cancer}

Unlike oncomiRs, TSmiRs plays a critical role in preventing cancer progression in various organs, including the pancreas, by blocking oncogene function in cancer cells. Several TSmiRs expressions were undetected or minimally detected in pancreatic cancer cells. Enforced expressions of these TSmiRs in cancer cells induce cell growth inhibition and apoptosis. Six of these TsmiRs are described below: 


\subsection{The miRNA-200 Family}

The miR-200 family consists of five members (miR-200a, miR-200b, miR-200c, miR-141 and miR-429) and can be grouped into two subfamilies based on chromosomal localization and seed sequence [134]. The members of first subfamily are grouped into two clusters: cluster I, containing miR-200a, miR-200b and miR-429, is located on chromosome 1p36, and cluster II contains miR-200c and miR-141, located on chromosome 12p13. The members of second subfamily can be divided into two functional groups: functional group I contains miR-200b, $-200 \mathrm{c}$ and -429 , and functional group II consists of miR-200a and -141. Both share the same seed sequence except one nucleotide (AAUACUG for functional group I and AACACUG for functional group II); thus, they regulate different target genes in cancer (Figure 2) $[48,51,52,54]$. The tumor suppressive role of the miR-200 family has been reported in several cancers like breast cancer [135-139], renal cancer [140-142], colon cancer [143,144], prostate cancer [145-147], ovarian cancer [51] and non-small cell lung cancer [148,149]. The aberrant expression of the miR-200 family in pancreatic cancer and its involvement in cancer initiation and progression has been well-demonstrated [25,91,150-153]. The miR-200 family members have proven to be a key regulator of EMT, a critical step in invasion and metastasis in various cancers $[51,134,141,149,151,154]$. The transcriptional repressor zinc-finger E-box binding homeobox 1 and 2 (ZEB1 and ZEB2) are crucial inducers of EMT in various cancers and have been shown to promote invasion and metastasis of cancer cells $[155,156]$. An inverse relation between ZEB1 and the miR-200 family members has been reported to promote EMT and invasion in various cancers, including pancreatic cancer [51,149-151,153,157-160]. The miR-200 family is not only able to inhibit EMT but is also capable of suppressing tumor growth in different xenograft models [147,161-165]. However, a reverse effect of miR-200 family members was reported in colorectal cancer.

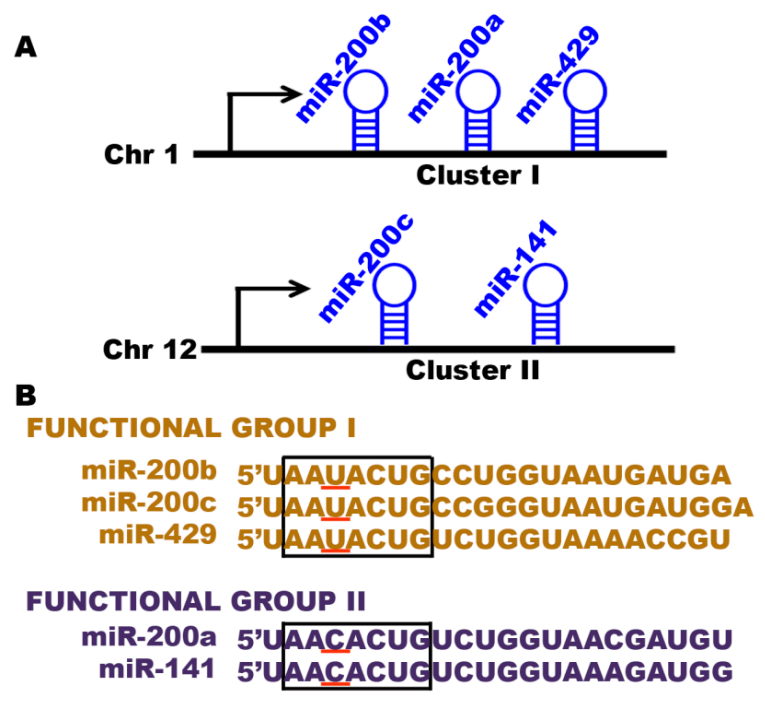

Figure 2. The miR-200 family members. (A) The human miR-200 family members are grouped into two clusters: cluster I containing miR-200a, miR-200b, and miR-429 is located on chromosome 1p36, and cluster II contains miR-200c and miR-141, which is located on chromosome 12p13; (B) The human miR-200 family members are based on the similarities of their seed sequences (sequence under the box in which one nucleotide is specific for each group (underline)). Members can be divided into two functional groups: functional group I contains miR-200b, -200c, and -429 , and functional group II consists of miR-200a and -141, distinguished by a single nucleotide change ( $U$ to $C$ ).

Tumor angiogenesis, the formation of new abnormal blood vessels from the existing ones, is a vital, pathological process required for tumor progression and metastasis [166]. Tumor angiogenesis can be blocked by the miR-200 family members via targeting the VEGF signaling pathway components, such as VEGF-A, FLT1/VEGFR1, and KDR/VEGFR2 [49]. Inhibition of VEGFR1 and VEGFR2 by 
miR-200 family members resulted in the inhibition of tumor growth and angiogenesis in mouse models of PDAC [162]. The overexpression of membrane type-1 matrix metalloproteinase (MT1-MMP) and lesser expression of phosphatase and tensin homolog (PTEN) have been associated with angiogenesis in pancreatic carcinogenesis $[167,168]$. Interestingly, miR-200c blocks the expression of MT1-MMP with concomitantly increased expression of PTEN in pancreatic cancer cells [152], suggesting that miR200c induced inhibition of tumor angiogenesis could be mediated through the regulation of MT1-MMP and PTEN.

Like other cancers, cancer stem cells play a vital role in tumorigenesis and drug resistance of pancreatic cancer [169]. Several other markers like ABCG2, CD133, ALDH1 and c-Met were identified as CSC/Cancer initiating cell markers [170-172]. Interestingly, the miR-200 family members are able to regulate the self-renewal capacity of PC stem cells via regulating multiple gene signatures associated with these events [20,173-175].

\subsection{MicroRNA-34a (miR-34a)}

MiR-34a gene is located on chromosome $1 \mathrm{p} 36.22$ and acts as a potential tumor suppressor in pancreatic cancer [55-57] as well as other cancers [176-180]. MiR-34 could be a negative regulator of pancreatic cancer stem cells (PCSCs) growth and survival as CD133+/CD44+ PCSC numbers is decreased by $87 \%$ after miR-34 restoration [57]. The activation of mir-34a in pancreatic cancer stem cells by 5 -azacytidine (demethylating agent) or SAHA (histone deacetylase inhibitor) resulted inhibition of cell proliferation, cell cycle progression, self-renewal, EMT and invasion with concomitant down-regulation of cyclin D1, CDK4, SIRT1, survivin, Bcl-2, VEGF, and CDK6 and upregulation of p27 ${ }^{\text {Kip1 }}$, P21 ${ }^{\text {Cip1 }}$ and PUMA [59]. Moreover, replacement of miR-34a through systematic delivery greatly suppressed the growth of pancreatic cancer in a xenograft model [181]. Collectively, these studies indicate that the tumor suppressor miR-34a could be a druggable target for pancreatic cancer therapy; however, further studies are warranted.

\subsection{MicroRNA-146a (miR-146a)}

The role of miR-146a can vary in different types of cancers. It can act as an oncomiR in several cancers, including thyroid cancer [182,183], acute promyelocytic leukemia [184] and cervical cancer [185]. Conversely, miR-146a is also a known tumor suppressor in prostate cancer [186], gastric cancer [187,188], breast [189,190], non-small cell lung cancer [191] and pancreatic cancer [192].

\subsection{MicroRNA-124 (miR-124)}

MiR-124 is represented in three genomic loci (miR-124-1 (8p23.1), miR-124-2 (8q12.3) and miR-124-3 (20q13.33)) [67]. MiR-124 has been reported as a tumor suppressor in various cancers including, pancreatic cancer $[67,115,193-196]$, and interacts with the $3^{\prime}$-UTR of its target, Rac1, to suppress MKK4-JNK-c-Jun-mediated cellular proliferation, invasion and metastasis. Moreover, miR124 known to regulate multiple proliferation-related genes in pancreatic cancer cells such as cyclin-dependent kinase 6 [197,198], Cyclin A2 [199], forkhead box A2 [200] and solute carrier family 16, member 1 (SLC16A1) [197].

Hunt $e$ al. showed that miR-124 could also suppress the motility of cancer cells by interacting with $3^{\prime}$-UTR of integrin $\beta 1$ (ITGB1) [63]. Numerous studies report that miR-124 targets an enhancer of zeste homolog 2 (EZH2), an important transcription factor involved in the proliferation and metastasis of tumor cells [64,66]. MiR-124 is also found to reduce cancer cell aggressiveness by directly targeting rho-kinase2 (ROCK2), an oncogene [64]. Recently, Asuthkar et al. examined the inverse relationship between miR-124 and urokinase plasminogen activator (uPA) in pancreatic cancer [201]. They found that uPA is highly expressed while miR-124 is downregulated in pancreatic cancer. Less miR-124 expression results in higher expression of its target LIM homeobox-2 (Lhx2), leading to pancreatic cancer cell stemness. 


\subsection{MicroRNA-203 (miR-203)}

MiR-203 is located at chromosome 14q32-33 [68]. MiR-203 was demonstrated to be highly expressed in PDAC samples when compared to normal pancreas tissue and in chronic pancreatitis, and miR-203 overexpression correlated with the worst prognosis in PDAC patients who underwent pancreatectomy [202].

A negative correlation between miR-203 and survivin expression in pancreatic cancer has been recently reported [203]. This study found that miR-203 suppresses the function of survivin by targeting its $3^{\prime}$-UTR and thereby leading to its loss of oncogenic function. Another study also witnesses the tumor suppressive role of miR-203 [69]. Despite discrepancy in the functional role of miR-203, multiple studies suggest that miR-203 prevents PC growth.

\subsection{Other TSmiRs in Pancreatic Cancer}

MiR-615-5p is located within CpG islands of the HOXC5 gene intron at chromosome 12q13.13 and functions as an outstanding tumor suppressor in hepatocellular carcinoma via inhibition of insulin-like growth factor 2 (IGF-2) [70,71]. Recent studies proved that, compared to adjacent, normal pancreatic tissues, there is significantly lower expression of miR-615-5p in PDAC tissues, as well as an overexpression of miR-615-5p inhibited pancreatic cancer cell proliferation, migration and invasion in vitro. MiR-615-5p also inhibited tumor growth and metastasis in vivo by targeting $3^{\prime}$-UTR of AKT2, a major downstream effector of phosphatidylinositol3-kinase. Downregulation of miR-615-5p limits its inhibitory effect on IGF-2 and other targets, such as proto-oncogene JUNB, which results in increased tumor growth, invasion and migration capabilities in PDAC cells [73]. miR-206 functions as a tumor suppressor in pancreatic cancer by inhibiting metastatic cell invasion and overall tumor growth and proliferation through the targeting of oncogenic K-Ras, an initiator of PDAC and of ANXA2, a regulator of extra cellular matrix degradation [74]. TSmiR, miR-96 has been reported to inhibit pancreatic cancer cell proliferation, migration and invasion by $3^{\prime}$-UTR of Novel (nua) kinase family 1 (NUAK1), an oncogene in pancreatic cancer [75]. Ectopic expression of miR-96 significantly inhibits malignant behavior of pancreatic cancer cells in vitro and in vivo by targeting the human ether-a-go-go-related potassium channel (HERG1), whose expression is significantly related to the development of pancreatic cancer [76]. MiR-96 has been shown to inhibit pancreatic cancer cell migration, invasion and growth by targeting both K-Ras and Akt signaling [77]. Recently, Guo et al. found that miR-410 acts as a TSmiR which suppresses pancreatic cancer growth, cell invasion, migration and angiogenesis by targeting angiotensin II type 1 receptor (AGTR1) [78]. Tsuda et al. demonstrated that miR-3548 inhibits cell division and induce late apoptosis in pancreatic tumor cells by targeting Gli-1 transcription factor, a downstream hedgehog signaling component [79].

\section{The Therapeutic Potential of MicroRNAs in Pancreatic Cancer}

Because of the under- or overexpression of miRNA in cancers, a strong potential for miRNA-based therapeutics exists. Since miRNA exists in all tissues, an aberrant expression of miRNA is not difficult to find. Each miRNA strand has the same effect on the cancer, so using them provides a specific and almost flawless method of combative treatment. In addition, the reintroduction of certain strands does have the ability to increase tumor chemosensitivity [204]. Multiple methods have been experimented on to introduce the miRNA mimic or the anti-miRNA strand into the tumor to restore tumor-suppressor miRNA function or inhibiting the function of oncogenic miRNAs, respectively. Some methods include lipid-based carriers, Cationic polymers, inorganic compounds such as gold and silica-based compounds, and exosomes [204-207]. Nanovectors can then be created using these carriers which will help transport the miRNA to the right cancer as the nanovector will be coated with specific antibodies $[127,208]$. Each person afflicted with cancer can treat themselves using customized medicine as a result of the many types of miRNA strands in cancer and the multiple types of delivery systems available [207]. Furthermore, the advancements of nanotechnology could potentially bring 
new types of delivery systems that both diagnoses and treats a specific types of tumor, and this would greatly increase lifespan and stop the cancer from advancing. Finally, a perfect match is not required for miRNA to bind with mRNA. Only a match between seven consecutive nucleotides is necessary to bind with mRNA, so a safety margin exists, which will help decrease the time needed to create the miRNA mimic or anti-miRNA strand [209].

Recently, therapeutic potential of miRNAs in pancreatic cancer has been demonstrated by a series of in vitro and in vivo studies. Pramanik et al. have synthesized a lipid based nanoparticle for systemic delivery of miR-34a (a tumor suppressor) expression vectors to cancer cells and, by doing so, have revealed the therapeutic value of reestablishing miR-34a expression in orthotopic and subcutaneous pancreatic xenograft models [208]. Furthermore, they also have shown that overexpression of miR-34a may improve the chemotherapeutic effect of traditional chemotherapy agents (e.g., gemcitabine) in pancreatic cancer [208].

MiR-21 overexpression is associated with increased proliferation, invasive properties, gemcitabine chemo-resistance and poor survival in pancreatic cancer patients [85-89,210]. Thus, targeting miR-21 strongly inhibits pancreatic cancer cell proliferation, induces apoptosis and inhibits pancreatic tumor growth in xenograft model [211]. Moreover, targeting miR-21 may stimulate angiogenesis, which may augment tumor drug delivery to enhance the efficacy of gemcitabine. Collectively, it has been shown that inhibition of oncomiRs or re-expression of TS-miRs can sensitize PC cells to the traditional anticancer drugs.

\section{Pitfalls of miRNA Therapy}

Despite having many benefits, pitfalls of miRNA therapy exist. First, miRNA degrades quickly in the blood stream [205]. This occurs as the body believes that the miRNA is an alien and deadly particle, leading to an immune response which kills off the miRNA [205]. Additionally, when the anti-miRNA or miRNA mimic is introduced, the strand may bind to the wrong mRNA which may produce undesired side effects and toxicity [212]. This may occur if the miRNA that was administered into the body creates a better match with another mRNA other than the target mRNA. This comes as a direct drawback from the aforementioned benefit of only requiring a limited amount of nucleotides that needed to be correct. In addition, a certain strand of miRNA may suppress one type of tumor while acting as an oncogene in another tumor. For example, miR-125 acts as a tumor suppressor in breast and bladder cancer, while the same strand of miRNA acts as an oncomiR in pancreatic cancer [207]. This may prove especially difficult when trying to target a specific type of cancer without creating any harsh side effects such as accidently creating another cancer. Finally, despite the advancements in nanotechnology, the creation of nanoparticle delivery systems still remains very costly [205].

\section{Conclusions}

MicroRNAs represent critical regulators of gene expression and have a wide variety of functions such as tumor cell differentiation, proliferation, cell cycle progression, invasion, and metastasis leading to pancreatic cancer progression. These miRNAs have been described as oncogenes or tumor suppressors (Tables 1 and 2 Figure 3) and many of them are used for diagnosis and as prognostic or predictive tools. Using this data, miRNAs can be used as therapeutic agents to combat pancreatic cancer. However, transportation methods for the miRNAs may induce toxicity, so more research is necessary to understand the effects of introducing a carrier into the body. Further work to identify downstream targets of these miRNAs will bring greater comprehension regarding their mode of action and shine a fresh light on using miRNAs clinically as biomarkers or therapeutic targets to combat pancreatic cancer. 


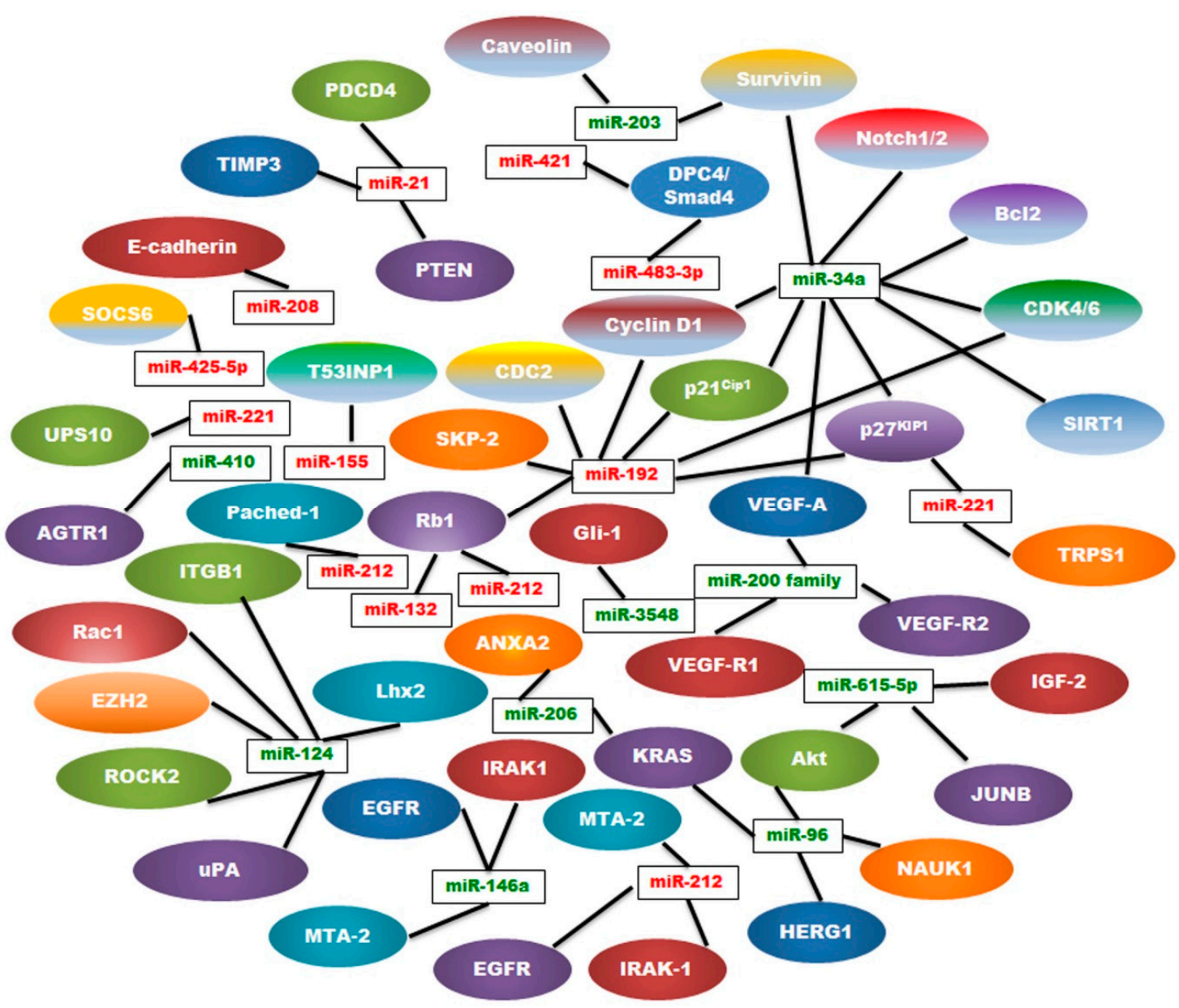

Figure 3. Gene regulatory network of several miRNAs (oncomiRs in red and TSmiRs in green) and their targets in pancreatic cancer.

Acknowledgments: We would like to thank the other members of our cancer research unit for valuable and helpful comments on this manuscript. We would also like to thank LaCoiya Harris for editing and organizing this manuscript. This work was supported by the Kansas City Area Life Science grant award (Sushanta K. Banerjee), Merit review grant from Department of Veterans Affairs (Sushanta K. Banerjee, 5I01BX001989-03 and SB,1I01BX001002-04), KUMC Van Goethem Family Endowed Funds (Sushanta K. Banerjee) and Basic Research Development Award from Internal Medicine, KUMC (Inamul Haque).

Author Contributions: Zuhair Hawa and Inamul Haque performed the literature search and wrote the manuscript. Arnab Ghosh and LaCoiya Harris revised it critically for important intellectual content. Snigdha Banerjee and Sushanta K. Banerjee provided expert comments and editing.

Conflicts of Interest: The authors declare no conflict of interest.

\section{References}

1. Arora, S.; Bhardwaj, A.; Singh, S.; Srivastava, S.K.; McClellan, S.; Nirodi, C.S.; Piazza, G.A.; Grizzle, W.E.; Owen, L.B.; Singh, A.P. An undesired effect of chemotherapy: Gemcitabine promotes pancreatic cancer cell invasiveness through reactive oxygen species-dependent, nuclear factor $\mathrm{kb}$ - and hypoxia-inducible factor $1 \alpha$-mediated up-regulation of CXCR4. J. Biol. Chem. 2013, 288, 21197-21207. [CrossRef] [PubMed]

2. Haque, I.; Mehta, S.; Majumder, M.; Dhar, K.; De, A.; McGregor, D.; Van Veldhuizen, P.J.; Banerjee, S.K.; Banerjee, S. Cyr61/ccn1 signaling is critical for epithelial-mesenchymal transition and stemness and promotes pancreatic carcinogenesis. Mol. Cancer 2011, 10, 8. [CrossRef] [PubMed]

3. Sebolt-Leopold, J.S.; English, J.M. Mechanisms of drug inhibition of signalling molecules. Nature 2006, 441, 457-462. [CrossRef] [PubMed] 
4. Li, M.; Marin-Muller, C.; Bharadwaj, U.; Chow, K.H.; Yao, Q.; Chen, C. MicroRNAs: Control and loss of control in human physiology and disease. World J. Surg. 2009, 33, 667-684. [CrossRef] [PubMed]

5. Ni, X.; Yang, J.; Li, M. Imaging-guided curative surgical resection of pancreatic cancer in a xenograft mouse model. Cancer Lett. 2012, 324, 179-185. [CrossRef] [PubMed]

6. Shi, S.; Yao, W.; Xu, J.; Long, J.; Liu, C.; Yu, X. Combinational therapy: New hope for pancreatic cancer? Cancer Lett. 2012, 317, 127-135. [CrossRef] [PubMed]

7. Sartel, D.P. MicroRNAs: Target recognition and regulatory functions. Cell 2009, 136, 215-233.

8. Calin, G.A.; Croce, C.M. MicroRNA signatures in human cancers. Nat. Rev. Cancer 2006, 6, 857-866. [CrossRef] [PubMed]

9. Calin, G.A.; Croce, C.M. MicroRNAs and chromosomal abnormalities in cancer cells. Oncogene 2006, 25, 6202-6210. [CrossRef] [PubMed]

10. Calin, G.A.; Sevignani, C.; Dumitru, C.D.; Hyslop, T.; Noch, E.; Yendamuri, S.; Shimizu, M.; Rattan, S.; Bullrich, F.; Negrini, M.; et al. Human microRNA genes are frequently located at fragile sites and genomic regions involved in cancers. Proc. Natl. Acad. Sci. USA 2004, 101, 2999-3004. [CrossRef] [PubMed]

11. Zhang, B.; Pan, X.; Cobb, G.P.; Anderson, T.A. MicroRNAs as oncogenes and tumor suppressors. Dev. Biol. 2007, 302, 1-12. [CrossRef] [PubMed]

12. Farhana, L.; Dawson, M.I.; Fontana, J.A. Down regulation of miR-202 modulates Mxd1 and Sin3a repressor complexes to induce apoptosis of pancreatic cancer cells. Cancer Biol. Ther. 2015, 16, 115-124. [CrossRef] [PubMed]

13. He, H.; Di, Y.; Liang, M.; Yang, F.; Yao, L.; Hao, S.; Li, J.; Jiang, Y.; Jin, C.; Fu, D. The microRNA-218 and robo-1 signaling axis correlates with the lymphatic metastasis of pancreatic cancer. Oncol. Rep. 2013, 30, 651-658. [PubMed]

14. Jiang, J.; Li, Z.; Yu, C.; Chen, M.; Tian, S.; Sun, C. MiR-1181 inhibits stem cell-like phenotypes and suppresses sox2 and stat3 in human pancreatic cancer. Cancer Lett. 2015, 356, 962-970. [CrossRef] [PubMed]

15. Jin, X.; Sun, Y.; Yang, H.; Li, J.; Yu, S.; Chang, X.; Lu, Z.; Chen, J. Deregulation of the miR-193b-kras axis contributes to impaired cell growth in pancreatic cancer. PLoS ONE 2015, 10, e0125515. [CrossRef] [PubMed]

16. Li, L.; Li, B.; Chen, D.; Liu, L.; Huang, C.; Lu, Z.; Lun, L.; Wan, X. MiR-139 and miR-200c regulate pancreatic cancer endothelial cell migration and angiogenesis. Oncol. Rep. 2015, 34, 51-58. [CrossRef] [PubMed]

17. Liu, Y.; Li, X.; Zhu, S.; Zhang, J.G.; Yang, M.; Qin, Q.; Deng, S.C.; Wang, B.; Tian, K.; Liu, L.; et al. Ectopic expression of miR-494 inhibited the proliferation, invasion and chemoresistance of pancreatic cancer by regulating sirt1 and c-Myc. Gene Ther. 2015, 22, 729-738. [CrossRef] [PubMed]

18. Xiao, J.; Peng, F.; Yu, C.; Wang, M.; Li, X.; Li, Z.; Jiang, J.; Sun, C. MicroRNA-137 modulates pancreatic cancer cells tumor growth, invasion and sensitivity to chemotherapy. Int. J. Clin. Exp. Pathol. 2014, 7, 7442-7450. [PubMed]

19. Zhang, Z.L.; Bai, Z.H.; Wang, X.B.; Bai, L.; Miao, F.; Pei, H.H. MiR-186 and 326 predict the prognosis of pancreatic ductal adenocarcinoma and affect the proliferation and migration of cancer cells. PLOS ONE 2015, 10, e0118814. [CrossRef] [PubMed]

20. Lam, S.S.; Mak, A.S.; Yam, J.W.; Cheung, A.N.; Ngan, H.Y.; Wong, A.S. Targeting estrogen-related receptor $\alpha$ inhibits epithelial-to-mesenchymal transition and stem cell properties of ovarian cancer cells. Mol. Ther. 2014, 22, 743-751. [CrossRef] [PubMed]

21. Lin, M.S.; Chen, W.C.; Huang, J.X.; Gao, H.J.; Sheng, H.H. Aberrant expression of microRNAs in serum may identify individuals with pancreatic cancer. Int. J. Clin. Exp. Med. 2014, 7, 5226-5234. [PubMed]

22. Papaconstantinou, I.G.; Lykoudis, P.M.; Gazouli, M.; Manta, A.; Polymeneas, G.; Voros, D. A review on the role of microRNA in biology, diagnosis, and treatment of pancreatic adenocarcinoma. Pancreas 2012, 41, 671-677. [CrossRef] [PubMed]

23. Xue, Y.; Abou Tayoun, A.N.; Abo, K.M.; Pipas, J.M.; Gordon, S.R.; Gardner, T.B.; Barth, R.J., Jr.; Suriawinata, A.A.; Tsongalis, G.J. MicroRNAs as diagnostic markers for pancreatic ductal adenocarcinoma and its precursor, pancreatic intraepithelial neoplasm. Cancer Genet. 2013, 206, 217-221. [CrossRef] [PubMed]

24. Yu, J.; Li, A.; Hong, S.M.; Hruban, R.H.; Goggins, M. MicroRNA alterations of pancreatic intraepithelial neoplasias. Clin. Cancer Res. 2012, 18, 981-992. [CrossRef] [PubMed]

25. Bao, B.; Ali, S.; Banerjee, S.; Wang, Z.; Logna, F.; Azmi, A.S.; Kong, D.; Ahmad, A.; Li, Y.; Padhye, S.; et al. Curcumin analogue CDF inhibits pancreatic tumor growth by switching on suppressor microRNAs and attenuating EZH2 expression. Cancer Res. 2012, 72, 335-345. [CrossRef] [PubMed] 
26. Giovannetti, E.; Funel, N.; Peters, G.J.; Del Chiaro, M.; Erozenci, L.A.; Vasile, E.; Leon, L.G.; Pollina, L.E.; Groen, A.; Falcone, A.; et al. MicroRNA-21 in pancreatic cancer: Correlation with clinical outcome and pharmacologic aspects underlying its role in the modulation of gemcitabine activity. Cancer Res. 2010, 70, 4528-4538. [CrossRef] [PubMed]

27. Ribas, J.; Ni, X.; Castanares, M.; Liu, M.M.; Esopi, D.; Yegnasubramanian, S.; Rodriguez, R.; Mendell, J.T.; Lupold, S.E. A novel source for miR-21 expression through the alternative polyadenylation of VMP1 gene transcripts. Nucleic Acids Res. 2012, 40, 6821-6833. [CrossRef] [PubMed]

28. Lloyd, R.V.; Erickson, L.A.; Jin, L.; Kulig, E.; Qian, X.; Cheville, J.C.; Scheithauer, B.W. p27kip1: A multifunctional cyclin-dependent kinase inhibitor with prognostic significance in human cancers. Am. J. Pathol. 1999, 154, 313-323. [CrossRef]

29. Kawaguchi, T.; Komatsu, S.; Ichikawa, D.; Morimura, R.; Tsujiura, M.; Konishi, H.; Takeshita, H.; Nagata, H.; Arita, T.; Hirajima, S.; et al. Clinical impact of circulating miR-221 in plasma of patients with pancreatic cancer. Br. J. Cancer 2013, 108, 361-369. [CrossRef] [PubMed]

30. Galardi, S.; Mercatelli, N.; Giorda, E.; Massalini, S.; Frajese, G.V.; Ciafre, S.A.; Farace, M.G. MiR-221 and miR-222 expression affects the proliferation potential of human prostate carcinoma cell lines by targeting p27kip1. J. Biol. Chem. 2007, 282, 23716-23724. [CrossRef] [PubMed]

31. Su, A.; He, S.; Tian, B.; Hu, W.; Zhang, Z. MicroRNA-221 mediates the effects of pdgf-bb on migration, proliferation, and the epithelial-mesenchymal transition in pancreatic cancer cells. PLoS ONE 2013, 8, e71309. [CrossRef] [PubMed]

32. Tam, W. Identification and characterization of human bic, a gene on chromosome 21 that encodes a noncoding RNA. Gene 2001, 274, 157-167. [CrossRef]

33. Seux, M.; Peuget, S.; Montero, M.P.; Siret, C.; Rigot, V.; Clerc, P.; Gigoux, V.; Pellegrino, E.; Pouyet, L.; N'Guessan, P.; et al. Tp53inp1 decreases pancreatic cancer cell migration by regulating SPARC expression. Oncogene 2011, 30, 3049-3061. [CrossRef] [PubMed]

34. Gironella, M.; Seux, M.; Xie, M.J.; Cano, C.; Tomasini, R.; Gommeaux, J.; Garcia, S.; Nowak, J.; Yeung, M.L.; Jeang, K.T.; et al. Tumor protein 53-induced nuclear protein 1 expression is repressed by miR-155, and its restoration inhibits pancreatic tumor development. Proc. Natl. Acad. Sci. USA 2007, 104, 16170-16175. [CrossRef] [PubMed]

35. Ma, L. Role of miR-10b in breast cancer metastasis. Breast Cancer Res. 2010, 12, 210. [CrossRef] [PubMed]

36. Ma, L.; Teruya-Feldstein, J.; Weinberg, R.A. Tumour invasion and metastasis initiated by microRNA-10b in breast cancer. Nature 2007, 449, 682-688. [CrossRef] [PubMed]

37. Ouyang, M.; Li, Y.; Ye, S.; Ma, J.; Lu, L.; Lv, W.; Chang, G.; Li, X.; Li, Q.; Wang, S.; et al. MicroRNA profiling implies new markers of chemoresistance of triple-negative breast cancer. PLoS ONE 2014, 9, e96228. [CrossRef] [PubMed]

38. Liu, A.; Shao, C.; Jin, G.; Liu, R.; Hao, J.; Song, B.; Ouyang, L.; Hu, X. MiR-208-induced epithelial to mesenchymal transition of pancreatic cancer cells promotes cell metastasis and invasion. Cell Biochem. Biophys. 2014, 69, 341-346. [CrossRef] [PubMed]

39. Li, H.; Zheng, D.; Zhang, B.; Liu, L.; Ou, J.; Chen, W.; Xiong, S.; Gu, Y.; Yang, J. MiR-208 promotes cell proliferation by repressing sox6 expression in human esophageal squamous cell carcinoma. J. Transl. Med. 2014, 12, 196. [CrossRef] [PubMed]

40. Feng, S.; Cong, S.; Zhang, X.; Bao, X.; Wang, W.; Li, H.; Wang, Z.; Wang, G.; Xu, J.; Du, B.; et al. MicroRNA-192 targeting retinoblastoma 1 inhibits cell proliferation and induces cell apoptosis in lung cancer cells. Nucleic Acids Res. 2011, 39, 6669-6678. [CrossRef] [PubMed]

41. Zhao, C.; Zhang, J.; Zhang, S.; Yu, D.; Chen, Y.; Liu, Q.; Shi, M.; Ni, C.; Zhu, M. Diagnostic and biological significance of microRNA-192 in pancreatic ductal adenocarcinoma. Oncol. Rep. 2013, 30, 276-284. [CrossRef] [PubMed]

42. Wu, K.; Hu, G.; He, X.; Zhou, P.; Li, J.; He, B.; Sun, W. MicroRNA-424-5p suppresses the expression of socs6 in pancreatic cancer. Pathol. Oncol. Res. 2013, 19, 739-748. [CrossRef] [PubMed]

43. Hao, J.; Zhang, S.; Zhou, Y.; Hu, X.; Shao, C. MicroRNA 483-3p suppresses the expression of DPC4/SMAD4 in pancreatic cancer. FEBS Lett. 2011, 585, 207-213. [CrossRef] [PubMed]

44. Hao, J.; Zhang, S.; Zhou, Y.; Liu, C.; Hu, X.; Shao, C. MicroRNA 421 suppresses DPC4/SMAD4 in pancreatic cancer. Biochem. Biophys. Res. Commun. 2011, 406, 552-557. [CrossRef] [PubMed] 
45. Park, J.K.; Henry, J.C.; Jiang, J.; Esau, C.; Gusev, Y.; Lerner, M.R.; Postier, R.G.; Brackett, D.J.; Schmittgen, T.D. MiR-132 and miR-212 are increased in pancreatic cancer and target the retinoblastoma tumor suppressor. Biochem. Biophys. Res. Commun. 2011, 406, 518-523. [CrossRef] [PubMed]

46. Liu, H.; Xu, X.F.; Zhao, Y.; Tang, M.C.; Zhou, Y.Q.; Lu, J.; Gao, F.H. MicroRNA-191 promotes pancreatic cancer progression by targeting usp10. Tumour Biol. 2014, 35, 12157-12163. [CrossRef] [PubMed]

47. Ma, C.; Nong, K.; Wu, B.; Dong, B.; Bai, Y.; Zhu, H.; Wang, W.; Huang, X.; Yuan, Z.; Ai, K. MiR-212 promotes pancreatic cancer cell growth and invasion by targeting the hedgehog signaling pathway receptor patched-1. J. Exp. Clin. Cancer Res. 2014, 33, 54. [CrossRef] [PubMed]

48. Feng, X.; Wang, Z.; Fillmore, R.; Xi, Y. MiR-200, a new star miRNA in human cancer. Cancer Lett. 2014, 344, 166-173. [CrossRef] [PubMed]

49. Zhang, H.F.; Xu, L.Y.; Li, E.M. A family of pleiotropically acting microRNAs in cancer progression, miR-200: Potential cancer therapeutic targets. Curr. Pharm. Des. 2014, 20, 1896-1903. [CrossRef] [PubMed]

50. Hilmarsdottir, B.; Briem, E.; Bergthorsson, J.T.; Magnusson, M.K.; Gudjonsson, T. Functional role of the microRNA-200 family in breast morphogenesis and neoplasia. Genes 2014, 5, 804-820. [CrossRef] [PubMed]

51. Park, S.M.; Gaur, A.B.; Lengyel, E.; Peter, M.E. The miR-200 family determines the epithelial phenotype of cancer cells by targeting the E-cadherin repressors ZEB1 and ZEB2. Genes Dev. 2008, 22, 894-907. [CrossRef] [PubMed]

52. Altuvia, Y.; Landgraf, P.; Lithwick, G.; Elefant, N.; Pfeffer, S.; Aravin, A.; Brownstein, M.J.; Tuschl, T.; Margalit, H. Clustering and conservation patterns of human microRNAs. Nucleic Acids Res. 2005, 33, 2697-2706. [CrossRef] [PubMed]

53. Uhlmann, S.; Zhang, J.D.; Schwager, A.; Mannsperger, H.; Riazalhosseini, Y.; Burmester, S.; Ward, A.; Korf, U.; Wiemann, S.; Sahin, O. MiR-200bc/429 cluster targets PLC $\gamma 1$ and differentially regulates proliferation and EGF-driven invasion than miR-200a/141 in breast cancer. Oncogene 2010, 29, 4297-4306. [CrossRef] [PubMed]

54. Humphries, B.; Yang, C. The microRNA-200 family: Small molecules with novel roles in cancer development, progression and therapy. Oncotarget 2015, 6, 6472-6498. [CrossRef] [PubMed]

55. Jamieson, N.B.; Morran, D.C.; Morton, J.P.; Ali, A.; Dickson, E.J.; Carter, C.R.; Sansom, O.J.; Evans, T.R.; McKay, C.J.; Oien, K.A. MicroRNA molecular profiles associated with diagnosis, clinicopathologic criteria, and overall survival in patients with resectable pancreatic ductal adenocarcinoma. Clin. Cancer Res. 2012, 18, 534-545. [CrossRef] [PubMed]

56. Luo, G.; Long, J.; Cui, X.; Xiao, Z.; Liu, Z.; Shi, S.; Liu, L.; Liu, C.; Xu, J.; Li, M.; et al. Highly lymphatic metastatic pancreatic cancer cells possess stem cell-like properties. Int. J. Oncol. 2013, 42, 979-984. [PubMed]

57. Ji, Q.; Hao, X.; Zhang, M.; Tang, W.; Yang, M.; Li, L.; Xiang, D.; Desano, J.T.; Bommer, G.T.; Fan, D.; et al. MicroRNA miR-34 inhibits human pancreatic cancer tumor-initiating cells. PLoS ONE 2009, 4, e6816. [CrossRef] [PubMed]

58. Lodygin, D.; Tarasov, V.; Epanchintsev, A.; Berking, C.; Knyazeva, T.; Korner, H.; Knyazev, P.; Diebold, J.; Hermeking, H. Inactivation of miR-34a by aberrant CpG methylation in multiple types of cancer. Cell Cycle 2008, 7, 2591-2600. [CrossRef] [PubMed]

59. Nalls, D.; Tang, S.N.; Rodova, M.; Srivastava, R.K.; Shankar, S. Targeting epigenetic regulation of miR-34a for treatment of pancreatic cancer by inhibition of pancreatic cancer stem cells. PLoS ONE 2011, 6, e24099. [CrossRef] [PubMed]

60. Azmi, A.S.; Ali, S.; Banerjee, S.; Bao, B.; Maitah, M.N.; Padhye, S.; Philip, P.A.; Mohammad, R.M.; Sarkar, F.H. Network modeling of CDF treated pancreatic cancer cells reveals a novel c-myc-p73 dependent apoptotic mechanism. Am. J. Transl. Res. 2011, 3, 374-382. [PubMed]

61. Li, Y.; Vandenboom, T.G., 2nd; Wang, Z.; Kong, D.; Ali, S.; Philip, P.A.; Sarkar, F.H. MiR-146a suppresses invasion of pancreatic cancer cells. Cancer Res. 2010, 70, 1486-1495. [CrossRef] [PubMed]

62. Li, Y.; VandenBoom, T.G., 2nd; Wang, Z.; Kong, D.; Ali, S.; Philip, P.A.; Sarkar, F.H. Up-regulation of miR-146a contributes to the inhibition of invasion of pancreatic cancer cells. Cancer Res. 2010, 70, 5703. [CrossRef] [PubMed]

63. Hunt, S.; Jones, A.V.; Hinsley, E.E.; Whawell, S.A.; Lambert, D.W. MicroRNA-124 suppresses oral squamous cell carcinoma motility by targeting itgb1. FEBS Lett. 2011, 585, 187-192. [CrossRef] [PubMed]

64. Zheng, F.; Liao, Y.J.; Cai, M.Y.; Liu, Y.H.; Liu, T.H.; Chen, S.P.; Bian, X.W.; Guan, X.Y.; Lin, M.C.; Zeng, Y.X.; et al. The putative tumour suppressor microRNA-124 modulates hepatocellular carcinoma cell aggressiveness by repressing ROCK2 and EZH2. Gut 2012, 61, 278-289. [CrossRef] [PubMed] 
65. Huang, S.D.; Yuan, Y.; Zhuang, C.W.; Li, B.L.; Gong, D.J.; Wang, S.G.; Zeng, Z.Y.; Cheng, H.Z. MicroRNA-98 and microRNA-214 post-transcriptionally regulate enhancer of zeste homolog 2 and inhibit migration and invasion in human esophageal squamous cell carcinoma. Mol. Cancer 2012, 11, 51. [CrossRef] [PubMed]

66. Xie, L.; Zhang, Z.; Tan, Z.; He, R.; Zeng, X.; Xie, Y.; Li, S.; Tang, G.; Tang, H.; He, X. MicroRNA-124 inhibits proliferation and induces apoptosis by directly repressing EZH2 in gastric cancer. Mol. Cell. Biochem. 2014, 392, 153-159. [CrossRef] [PubMed]

67. Wang, P.; Chen, L.; Zhang, J.; Chen, H.; Fan, J.; Wang, K.; Luo, J.; Chen, Z.; Meng, Z.; Liu, L. Methylation-mediated silencing of the miR-124 genes facilitates pancreatic cancer progression and metastasis by targeting Rac1. Oncogene 2014, 33, 514-524. [CrossRef] [PubMed]

68. Xu, M.; Gu, M.; Zhang, K.; Zhou, J.; Wang, Z.; Da, J. MiR-203 inhibition of renal cancer cell proliferation, migration and invasion by targeting of FGF2. Diagn. Pathol. 2015, 10, 24. [CrossRef] [PubMed]

69. Miao, L.; Xiong, X.; Lin, Y.; Cheng, Y.; Lu, J.; Zhang, J.; Cheng, N. MiR-203 inhibits tumor cell migration and invasion via caveolin-1 in pancreatic cancer cells. Oncol. Lett. 2014, 7, 658-662. [PubMed]

70. Song, L.J.; Zhang, W.J.; Chang, Z.W.; Pan, Y.F.; Zong, H.; Fan, Q.X.; Wang, L.X. Pu.1 is identified as a novel metastasis suppressor in hepatocellular carcinoma regulating the miR-615-5p/IGF2 axis. Asian Pac. J. Cancer Prev. 2015, 16, 3667-3671. [CrossRef] [PubMed]

71. El Tayebi, H.M.; Hosny, K.A.; Esmat, G.; Breuhahn, K.; Abdelaziz, A.I. MiR-615-5p is restrictedly expressed in cirrhotic and cancerous liver tissues and its overexpression alleviates the tumorigenic effects in hepatocellular carcinoma. FEBS Lett. 2012, 586, 3309-3316. [CrossRef] [PubMed]

72. Sun, Y.; Zhang, T.; Wang, C.; Jin, X.; Jia, C.; Yu, S.; Chen, J. MiRNA-615-5p functions as a tumor suppressor in pancreatic ductal adenocarcinoma by targeting AKT2. PLoS ONE 2015, 10, e0119783.

73. Gao, W.; Gu, Y.; Li, Z.; Cai, H.; Peng, Q.; Tu, M.; Kondo, Y.; Shinjo, K.; Zhu, Y.; Zhang, J.; et al. MiR-615-5p is epigenetically inactivated and functions as a tumor suppressor in pancreatic ductal adenocarcinoma. Oncogene 2015, 34, 1629-1640. [CrossRef] [PubMed]

74. Keklikoglou, I.; Hosaka, K.; Bender, C.; Bott, A.; Koerner, C.; Mitra, D.; Will, R.; Woerner, A.; Muenstermann, E.; Wilhelm, H.; et al. MicroRNA-206 functions as a pleiotropic modulator of cell proliferation, invasion and lymphangiogenesis in pancreatic adenocarcinoma by targeting ANXA2 and KRAS genes. Oncogene 2014, 34, 4867-4878. [CrossRef] [PubMed]

75. Huang, X.; Lv, W.; Zhang, J.H.; Lu, D.L. MiR96 functions as a tumor suppressor gene by targeting NUAK1 in pancreatic cancer. Int. J. Mol. Med. 2014, 34, 1599-1605. [PubMed]

76. Feng, J.; Yu, J.; Pan, X.; Li, Z.; Chen, Z.; Zhang, W.; Wang, B.; Yang, L.; Xu, H.; Zhang, G.; et al. Herg1 functions as an oncogene in pancreatic cancer and is downregulated by miR-96. Oncotarget 2014, 5, 5832-5844. [CrossRef] [PubMed]

77. Yu, S.; Lu, Z.; Liu, C.; Meng, Y.; Ma, Y.; Zhao, W.; Liu, J.; Yu, J.; Chen, J. MiRNA-96 suppresses Kras and functions as a tumor suppressor gene in pancreatic cancer. Cancer Res. 2010, 70, 6015-6025. [CrossRef] [PubMed]

78. Guo, R.; Gu, J.; Zhang, Z.; Wang, Y.; Gu, C. MicroRNA-410 functions as a tumor suppressor by targeting angiotensin ii type 1 receptor in pancreatic cancer. IUBMB Life 2015, 67, 42-53. [CrossRef] [PubMed]

79. Tsuda, N.; Ishiyama, S.; Li, Y.; Ioannides, C.G.; Abbruzzese, J.L.; Chang, D.Z. Synthetic microrna designed to target glioma-associated antigen 1 transcription factor inhibits division and induces late apoptosis in pancreatic tumor cells. Clin. Cancer Res. 2006, 12, 6557-6564. [CrossRef] [PubMed]

80. Macfarlane, L.A.; Murphy, P.R. MicroRNA: Biogenesis, function and role in cancer. Curr. Genom. 2010, 11, 537-561. [CrossRef] [PubMed]

81. Lee, Y.; Kim, M.; Han, J.; Yeom, K.H.; Lee, S.; Baek, S.H.; Kim, V.N. MicroRNA genes are transcribed by rna polymerase II. EMBO J. 2004, 23, 4051-4060. [CrossRef] [PubMed]

82. Han, J.; Lee, Y.; Yeom, K.H.; Kim, Y.K.; Jin, H.; Kim, V.N. The DROSHA-DGCR8 complex in primary microrna processing. Genes Dev. 2004, 18, 3016-3027. [CrossRef] [PubMed]

83. Kim, V.N. MicroRNA precursors in motion: Exportin-5 mediates their nuclear export. Trends Cell Biol. 2004, 14, 156-159. [CrossRef] [PubMed]

84. Lee, E.J.; Gusev, Y.; Jiang, J.; Nuovo, G.J.; Lerner, M.R.; Frankel, W.L.; Morgan, D.L.; Postier, R.G.; Brackett, D.J.; Schmittgen, T.D. Expression profiling identifies microRNA signature in pancreatic cancer. Int. J. Cancer 2007, 120, 1046-1054. [CrossRef] [PubMed] 
85. Bloomston, M.; Frankel, W.L.; Petrocca, F.; Volinia, S.; Alder, H.; Hagan, J.P.; Liu, C.G.; Bhatt, D.; Taccioli, C.; Croce, C.M. MicroRNA expression patterns to differentiate pancreatic adenocarcinoma from normal pancreas and chronic pancreatitis. JAMA 2007, 297, 1901-1908. [CrossRef] [PubMed]

86. Dillhoff, M.; Liu, J.; Frankel, W.; Croce, C.; Bloomston, M. MicroRNA-21 is overexpressed in pancreatic cancer and a potential predictor of survival. J. Gastrointest. Surg. 2008, 12, 2171-2176. [CrossRef] [PubMed]

87. Moriyama, T.; Ohuchida, K.; Mizumoto, K.; Yu, J.; Sato, N.; Nabae, T.; Takahata, S.; Toma, H.; Nagai, E.; Tanaka, M. MicroRNA-21 modulates biological functions of pancreatic cancer cells including their proliferation, invasion, and chemoresistance. Mol. Cancer Ther. 2009, 8, 1067-1074. [CrossRef] [PubMed]

88. Nagao, Y.; Hisaoka, M.; Matsuyama, A.; Kanemitsu, S.; Hamada, T.; Fukuyama, T.; Nakano, R.; Uchiyama, A.; Kawamoto, M.; Yamaguchi, K.; et al. Association of microRNA-21 expression with its targets, pdcd4 and timp3, in pancreatic ductal adenocarcinoma. Mod. Pathol. 2012, 25, 112-121. [CrossRef] [PubMed]

89. Szafranska, A.E.; Doleshal, M.; Edmunds, H.S.; Gordon, S.; Luttges, J.; Munding, J.B.; Barth, R.J., Jr.; Gutmann, E.J.; Suriawinata, A.A.; Marc Pipas, J.; et al. Analysis of microRNAs in pancreatic fine-needle aspirates can classify benign and malignant tissues. Clin. Chem. 2008, 54, 1716-1724. [CrossRef] [PubMed]

90. Du Rieu, M.C.; Torrisani, J.; Selves, J.; Al Saati, T.; Souque, A.; Dufresne, M.; Tsongalis, G.J.; Suriawinata, A.A.; Carrere, N.; Buscail, L.; et al. MicroRNA-21 is induced early in pancreatic ductal adenocarcinoma precursor lesions. Clin. Chem. 2010, 56, 603-612. [CrossRef] [PubMed]

91. Ali, S.; Ahmad, A.; Banerjee, S.; Padhye, S.; Dominiak, K.; Schaffert, J.M.; Wang, Z.; Philip, P.A.; Sarkar, F.H. Gemcitabine sensitivity can be induced in pancreatic cancer cells through modulation of miR-200 and miR-21 expression by curcumin or its analogue CDF. Cancer Res. 2010, 70, 3606-3617. [CrossRef] [PubMed]

92. Park, J.K.; Lee, E.J.; Esau, C.; Schmittgen, T.D. Antisense inhibition of microRNA-21 or -221 arrests cell cycle, induces apoptosis, and sensitizes the effects of gemcitabine in pancreatic adenocarcinoma. Pancreas 2009, 38, e190-e199. [CrossRef] [PubMed]

93. Liu, S.; Wang, X.J.; Liu, Y.; Cui, Y.F. Pi3K/AKT/mTOR signaling is involved in (-)-epigallocatechin3-gallate-induced apoptosis of human pancreatic carcinoma cells. Am. J. Chin. Med. 2013, 41, 629-642. [CrossRef] [PubMed]

94. Mace, T.A.; Collins, A.L.; Wojcik, S.E.; Croce, C.M.; Lesinski, G.B.; Bloomston, M. Hypoxia induces the overexpression of microRNA-21 in pancreatic cancer cells. J. Surg. Res. 2013, 184, 855-860. [CrossRef] [PubMed]

95. Basu, A.; Alder, H.; Khiyami, A.; Leahy, P.; Croce, C.M.; Haldar, S. MicroRNA-375 and microRNA-221: Potential noncoding RNAs associated with antiproliferative activity of benzyl isothiocyanate in pancreatic cancer. Genes Cancer 2011, 2, 108-119. [CrossRef] [PubMed]

96. Sarkar, S.; Dubaybo, H.; Ali, S.; Goncalves, P.; Kollepara, S.L.; Sethi, S.; Philip, P.A.; Li, Y. Down-regulation of miR-221 inhibits proliferation of pancreatic cancer cells through up-regulation of PTEN, p27(kip1), p57(kip2), and PUMA. Am. J. Cancer Res. 2013, 3, 465-477. [PubMed]

97. Volinia, S.; Calin, G.A.; Liu, C.G.; Ambs, S.; Cimmino, A.; Petrocca, F.; Visone, R.; Iorio, M.; Roldo, C.; Ferracin, M.; et al. A microRNA expression signature of human solid tumors defines cancer gene targets. Proc. Natl. Acad. Sci. USA 2006, 103, 2257-2261. [CrossRef] [PubMed]

98. Jiang, S.; Zhang, H.W.; Lu, M.H.; He, X.H.; Li, Y.; Gu, H.; Liu, M.F.; Wang, E.D. MicroRNA-155 functions as an oncomir in breast cancer by targeting the suppressor of cytokine signaling 1 gene. Cancer Res. 2010, 70, 3119-3127. [CrossRef] [PubMed]

99. Kong, W.; He, L.; Coppola, M.; Guo, J.; Esposito, N.N.; Coppola, D.; Cheng, J.Q. MicroRNA-155 regulates cell survival, growth, and chemosensitivity by targeting FOXO3a in breast cancer. J. Biol. Chem. 2010, 285, 17869-17879. [CrossRef] [PubMed]

100. Sochor, M.; Basova, P.; Pesta, M.; Dusilkova, N.; Bartos, J.; Burda, P.; Pospisil, V.; Stopka, T. Oncogenic microRNAs: MiR-155, miR-19a, miR-181b, and miR-24 enable monitoring of early breast cancer in serum. BMC Cancer 2014, 14, 448. [CrossRef] [PubMed]

101. Zhang, C.M.; Zhao, J.; Deng, H.Y. MiR-155 promotes proliferation of human breast cancer MCF-7 cells through targeting tumor protein 53-induced nuclear protein 1. J. Biomed. Sci. 2013, 20, 79. [CrossRef] [PubMed]

102. Babar, I.A.; Czochor, J.; Steinmetz, A.; Weidhaas, J.B.; Glazer, P.M.; Slack, F.J. Inhibition of hypoxia-induced miR-155 radiosensitizes hypoxic lung cancer cells. Cancer Biol. Ther. 2011, 12, 908-914. [CrossRef] [PubMed] 
103. Raponi, M.; Dossey, L.; Jatkoe, T.; Wu, X.; Chen, G.; Fan, H.; Beer, D.G. MicroRNA classifiers for predicting prognosis of squamous cell lung cancer. Cancer Res. 2009, 69, 5776-5783. [CrossRef] [PubMed]

104. Zheng, D.; Haddadin, S.; Wang, Y.; Gu, L.Q.; Perry, M.C.; Freter, C.E.; Wang, M.X. Plasma microRNAs as novel biomarkers for early detection of lung cancer. Int. J. Clin. Exp. Pathol. 2011, 4, 575-586. [PubMed]

105. Nikiforova, M.N.; Tseng, G.C.; Steward, D.; Diorio, D.; Nikiforov, Y.E. MicroRNA expression profiling of thyroid tumors: Biological significance and diagnostic utility. J. Clin. Endocrinol. Metab. 2008, 93, 1600-1608. [CrossRef] [PubMed]

106. Zhang, X.; Li, M.; Zuo, K.; Li, D.; Ye, M.; Ding, L.; Cai, H.; Fu, D.; Fan, Y.; Lv, Z. Upregulated miR-155 in papillary thyroid carcinoma promotes tumor growth by targeting apc and activating Wnt/ $\beta$-catenin signaling. J. Clin. Endocrinol. Metab. 2013, 98, E1305-E1313. [CrossRef] [PubMed]

107. Cai, Z.K.; Chen, Q.; Chen, Y.B.; Gu, M.; Zheng, D.C.; Zhou, J.; Wang, Z. MicroRNA-155 promotes the proliferation of prostate cancer cells by targeting annexin 7. Mol. Med. Rep. 2015, 11, 533-538. [PubMed]

108. Habbe, N.; Koorstra, J.B.; Mendell, J.T.; Offerhaus, G.J.; Ryu, J.K.; Feldmann, G.; Mullendore, M.E.; Goggins, M.G.; Hong, S.M.; Maitra, A. MicroRNA miR-155 is a biomarker of early pancreatic neoplasia. Cancer Biol. Ther. 2009, 8, 340-346. [CrossRef] [PubMed]

109. Ryu, J.K.; Hong, S.M.; Karikari, C.A.; Hruban, R.H.; Goggins, M.G.; Maitra, A. Aberrant microRNA-155 expression is an early event in the multistep progression of pancreatic adenocarcinoma. Pancreatology 2010, 10, 66-73. [CrossRef] [PubMed]

110. Wang, P.; Zhu, C.F.; Ma, M.Z.; Chen, G.; Song, M.; Zeng, Z.L.; Lu, W.H.; Yang, J.; Wen, S.; Chiao, P.J.; et al. Micro-RNA-155 is induced by K-Ras oncogenic signal and promotes ros stress in pancreatic cancer. Oncotarget 2015, 6, 21148-21158. [CrossRef] [PubMed]

111. Huang, C.; Li, H.; Wu, W.; Jiang, T.; Qiu, Z. Regulation of miR-155 affects pancreatic cancer cell invasiveness and migration by modulating the stat3 signaling pathway through socs1. Oncol. Rep. 2013, 30, 1223-1230. [PubMed]

112. Ghosh, A.; Ghosh, S.; Maiti, G.P.; Sabbir, M.G.; Zabarovsky, E.R.; Roy, A.; Roychoudhury, S.; Panda, C.K. Frequent alterations of the candidate genes hMLH1, ITGA9 and RBSP3 in early dysplastic lesions of head and neck: Clinical and prognostic significance. Cancer Sci. 2010, 101, 1511-1520. [CrossRef] [PubMed]

113. Greither, T.; Grochola, L.F.; Udelnow, A.; Lautenschlager, C.; Wurl, P.; Taubert, H. Elevated expression of microRNAs 155, 203, 210 and 222 in pancreatic tumors is associated with poorer survival. Int. J. Cancer 2010, 126, 73-80. [CrossRef] [PubMed]

114. Kishi, K.; Doki, Y.; Yano, M.; Yasuda, T.; Fujiwara, Y.; Takiguchi, S.; Kim, S.; Higuchi, I.; Monden, M. Reduced MLH1 expression after chemotherapy is an indicator for poor prognosis in esophageal cancers. Clin. Cancer Res. 2003, 9, 4368-4375. [PubMed]

115. Liu, W.J.; Zhao, Y.P.; Zhang, T.P.; Zhou, L.; Cui, Q.C.; Zhou, W.X.; You, L.; Chen, G.; Shu, H. MLH1 as a direct target of miR-155 and a potential predictor of favorable prognosis in pancreatic cancer. J. Gastrointest. Surg. 2013, 17, 1399-1405. [CrossRef] [PubMed]

116. Mackay, H.J.; Cameron, D.; Rahilly, M.; Mackean, M.J.; Paul, J.; Kaye, S.B.; Brown, R. Reduced MLH1 expression in breast tumors after primary chemotherapy predicts disease-free survival. J. Clin. Oncol. 2000, 18, 87-93. [PubMed]

117. Sinha, S.; Singh, R.K.; Alam, N.; Roy, A.; Roychoudhury, S.; Panda, C.K. Frequent alterations of hMLH1 and RBSP3/HYA22 at chromosomal 3p22.3 region in early and late-onset breast carcinoma: Clinical and prognostic significance. Cancer Sci. 2008, 99, 1984-1991. [PubMed]

118. Haque, I.; Banerjee, S.; Mehta, S.; De, A.; Majumder, M.; Mayo, M.S.; Kambhampati, S.; Campbell, D.R.; Banerjee, S.K. Cysteine-rich 61-connective tissue growth factor-nephroblastoma-overexpressed 5 (ccn5)/wnt-1-induced signaling protein-2 (wisp-2) regulates microRNA-10b via hypoxia-inducible factor-1alpha-twist signaling networks in human breast cancer cells. J. Biol. Chem. 2011, 286, 43475-43485. [CrossRef] [PubMed]

119. Allaya, N.; Khabir, A.; Sallemi-Boudawara, T.; Sellami, N.; Daoud, J.; Ghorbel, A.; Frikha, M.; Gargouri, A.; Mokdad-Gargouri, R.; Ayadi, W. Over-expression of miR-10b in npc patients: Correlation with $\operatorname{lmp} 1$ and twist1. Tumour Biol. 2015, 36, 3807-3814. [CrossRef] [PubMed]

120. Sun, X.J.; Liu, H.; Zhang, P.; Zhang, X.D.; Jiang, Z.W.; Jiang, C.C. MiR-10b promotes migration and invasion in nasopharyngeal carcinoma cells. Asian Pac. J. Cancer Prev. 2013, 14, 5533-5537. [CrossRef] [PubMed] 
121. Dong, C.G.; Wu, W.K.; Feng, S.Y.; Wang, X.J.; Shao, J.F.; Qiao, J. Co-inhibition of microRNA-10b and microRNA-21 exerts synergistic inhibition on the proliferation and invasion of human glioma cells. Int. J. Oncol. 2012, 41, 1005-1012. [PubMed]

122. Sasayama, T.; Nishihara, M.; Kondoh, T.; Hosoda, K.; Kohmura, E. MicroRNA-10b is overexpressed in malignant glioma and associated with tumor invasive factors, upar and rhoc. Int. J. Cancer 2009, 125, 1407-1413. [CrossRef] [PubMed]

123. Garzon, R.; Garofalo, M.; Martelli, M.P.; Briesewitz, R.; Wang, L.; Fernandez-Cymering, C.; Volinia, S.; Liu, C.G.; Schnittger, S.; Haferlach, T.; et al. Distinctive microRNA signature of acute myeloid leukemia bearing cytoplasmic mutated nucleophosmin. Proc. Natl. Acad. Sci. USA 2008, 105, 3945-3950. [CrossRef] [PubMed]

124. Tian, Y.; Luo, A.; Cai, Y.; Su, Q.; Ding, F.; Chen, H.; Liu, Z. MicroRNA-10b promotes migration and invasion through klf4 in human esophageal cancer cell lines. J. Biol. Chem. 2010, 285, 7986-7994. [CrossRef] [PubMed]

125. Nishida, N.; Yamashita, S.; Mimori, K.; Sudo, T.; Tanaka, F.; Shibata, K.; Yamamoto, H.; Ishii, H.; Doki, Y.; Mori, M. MicroRNA-10b is a prognostic indicator in colorectal cancer and confers resistance to the chemotherapeutic agent 5-fluorouracil in colorectal cancer cells. Ann. Surg. Oncol. 2012, 19, 3065-3071. [CrossRef] [PubMed]

126. Chai, G.; Liu, N.; Ma, J.; Li, H.; Oblinger, J.L.; Prahalad, A.K.; Gong, M.; Chang, L.S.; Wallace, M.; Muir, D.; et al. MicroRNA-10b regulates tumorigenesis in neurofibromatosis type 1. Cancer Sci. 2010, 101, 1997-2004. [CrossRef] [PubMed]

127. Nakata, K.; Ohuchida, K.; Mizumoto, K.; Kayashima, T.; Ikenaga, N.; Sakai, H.; Lin, C.; Fujita, H.; Otsuka, T.; Aishima, S.; et al. MicroRNA-10b is overexpressed in pancreatic cancer, promotes its invasiveness, and correlates with a poor prognosis. Surgery 2011, 150, 916-922. [CrossRef] [PubMed]

128. Preis, M.; Gardner, T.B.; Gordon, S.R.; Pipas, J.M.; Mackenzie, T.A.; Klein, E.E.; Longnecker, D.S.; Gutmann, E.J.; Sempere, L.F.; Korc, M. MicroRNA-10b expression correlates with response to neoadjuvant therapy and survival in pancreatic ductal adenocarcinoma. Clin. Cancer Res. 2011, 17, 5812-5821. [CrossRef] [PubMed]

129. Liao, C.G.; Kong, L.M.; Zhou, P.; Yang, X.L.; Huang, J.G.; Zhang, H.L.; Lu, N. MiR-10b is overexpressed in hepatocellular carcinoma and promotes cell proliferation, migration and invasion through rhoc, upar and mmps. J. Transl. Med. 2014, 12, 234. [CrossRef] [PubMed]

130. Guo, H.; Xu, Y.; Fu, Q. Curcumin inhibits growth of prostate carcinoma via miR-208-mediated cdkn1a activation. Tumour Biol. 2015, 36, 8511-8517. [CrossRef] [PubMed]

131. Jin, J.C.; Jin, X.L.; Zhang, X.; Piao, Y.S.; Liu, S.P. Effect of osw-1 on microRNA expression profiles of hepatoma cells and functions of novel microRNAs. Mol. Med. Rep. 2013, 7, 1831-1837. [CrossRef] [PubMed]

132. Halkova, T.; Cuperkova, R.; Minarik, M.; Benesova, L. MicroRNAs in pancreatic cancer: Involvement in carcinogenesis and potential use for diagnosis and prognosis. Gastroenterol. Res. Pract. 2015, 2015, 892903. [CrossRef] [PubMed]

133. Song, B.; Wang, Y.; Kudo, K.; Gavin, E.J.; Xi, Y.; Ju, J. MiR-192 regulates dihydrofolate reductase and cellular proliferation through the p53-microRNA circuit. Clin. Cancer Res. 2008, 14, 8080-8086. [CrossRef] [PubMed]

134. Korpal, M.; Kang, Y. The emerging role of miR-200 family of microRNAs in epithelial-mesenchymal transition and cancer metastasis. RNA Biol. 2008, 5, 115-119. [CrossRef] [PubMed]

135. Bai, J.X.; Yan, B.; Zhao, Z.N.; Xiao, X.; Qin, W.W.; Zhang, R.; Jia, L.T.; Meng, Y.L.; Jin, B.Q.; Fan, D.M.; et al. Tamoxifen represses miR-200 microRNAs and promotes epithelial-to-mesenchymal transition by up-regulating c-myc in endometrial carcinoma cell lines. Endocrinology 2013, 154, 635-645. [CrossRef] [PubMed]

136. Humphries, B.; Wang, Z.; Oom, A.L.; Fisher, T.; Tan, D.; Cui, Y.; Jiang, Y.; Yang, C. MicroRNA-200b targets protein kinase $c \alpha$ and suppresses triple-negative breast cancer metastasis. Carcinogenesis 2014, 35, 2254-2263. [CrossRef] [PubMed]

137. Knezevic, J.; Pfefferle, A.D.; Petrovic, I.; Greene, S.B.; Perou, C.M.; Rosen, J.M. Expression of miR-200c in claudin-low breast cancer alters stem cell functionality, enhances chemosensitivity and reduces metastatic potential. Oncogene 2015, 34, 5997-6006. [CrossRef] [PubMed]

138. Perdigao-Henriques, R.; Petrocca, F.; Altschuler, G.; Thomas, M.P.; Le, M.T.; Tan, S.M.; Hide, W.; Lieberman, J. MiR-200 promotes the mesenchymal to epithelial transition by suppressing multiple members of the zeb2 and snail1 transcriptional repressor complexes. Oncogene 2015, 35, 158-172. [CrossRef] [PubMed] 
139. Wang, C.H.; Chen, C.L.; More, S.V.; Hsiao, P.W.; Hung, W.C.; Li, W.S. The tetraindole sk228 reverses the epithelial-to-mesenchymal transition of breast cancer cells by up-regulating members of the miR-200 family. PLoS ONE 2014, 9, e101088. [CrossRef] [PubMed]

140. Duns, G.; van den Berg, A.; van Dijk, M.C.; van Duivenbode, I.; Giezen, C.; Kluiver, J.; van Goor, H.; Hofstra, R.M.; van den Berg, E.; Kok, K. The entire miR-200 seed family is strongly deregulated in clear cell renal cell cancer compared to the proximal tubular epithelial cells of the kidney. Genes Chromosomes Cancer 2013, 52, 165-173. [CrossRef] [PubMed]

141. Tamagawa, S.; Beder, L.B.; Hotomi, M.; Gunduz, M.; Yata, K.; Grenman, R.; Yamanaka, N. Role of $\mathrm{miR}-200 \mathrm{c} / \mathrm{miR}-141$ in the regulation of epithelial-mesenchymal transition and migration in head and neck squamous cell carcinoma. Int. J. Mol. Med. 2014, 33, 879-886. [PubMed]

142. Yoshino, H.; Enokida, H.; Itesako, T.; Tatarano, S.; Kinoshita, T.; Fuse, M.; Kojima, S.; Nakagawa, M.; Seki, N. Epithelial-mesenchymal transition-related microRNA-200s regulate molecular targets and pathways in renal cell carcinoma. J. Hum. Genet. 2013, 58, 508-516. [CrossRef] [PubMed]

143. Cai, Z.G.; Zhang, S.M.; Zhang, H.; Zhou, Y.Y.; Wu, H.B.; Xu, X.P. Aberrant expression of microRNAs involved in epithelial-mesenchymal transition of ht-29 cell line. Cell Biol. Int. 2013, 37, 669-674. [CrossRef] [PubMed]

144. Tian, Y.; Pan, Q.; Shang, Y.; Zhu, R.; Ye, J.; Liu, Y.; Zhong, X.; Li, S.; He, Y.; Chen, L.; et al. MicroRNA-200 (miR-200) cluster regulation by achaete scute-like 2 (ascl2): Impact on the epithelial-mesenchymal transition in colon cancer cells. J. Biol. Chem. 2014, 289, 36101-36115. [CrossRef] [PubMed]

145. He, M.; Liu, Y.; Deng, X.; Qi, S.; Sun, X.; Liu, G.; Liu, Y.; Liu, Y.; Zhao, M. Down-regulation of mir-200b-3p by low p73 contributes to the androgen-independence of prostate cancer cells. Prostate 2013, 73, 1048-1056. [CrossRef] [PubMed]

146. Kong, D.; Li, Y.; Wang, Z.; Banerjee, S.; Ahmad, A.; Kim, H.R.; Sarkar, F.H. MiR-200 regulates PDGF-D-mediated epithelial-mesenchymal transition, adhesion, and invasion of prostate cancer cells. Stem Cells 2009, 27, 1712-1721. [CrossRef] [PubMed]

147. Williams, L.V.; Veliceasa, D.; Vinokour, E.; Volpert, O.V. MiR-200b inhibits prostate cancer emt, growth and metastasis. PLoS ONE 2013, 8, e83991. [CrossRef] [PubMed]

148. Pacurari, M.; Addison, J.B.; Bondalapati, N.; Wan, Y.W.; Luo, D.; Qian, Y.; Castranova, V.; Ivanov, A.V.; Guo, N.L. The microRNA-200 family targets multiple non-small cell lung cancer prognostic markers in h1299 cells and beas-2b cells. Int. J. Oncol. 2013, 43, 548-560. [PubMed]

149. Schliekelman, M.J.; Gibbons, D.L.; Faca, V.M.; Creighton, C.J.; Rizvi, Z.H.; Zhang, Q.; Wong, C.H.; Wang, H.; Ungewiss, C.; Ahn, Y.H.; et al. Targets of the tumor suppressor miR-200 in regulation of the epithelial-mesenchymal transition in cancer. Cancer Res. 2011, 71, 7670-7682. [CrossRef] [PubMed]

150. Li, Y.; VandenBoom, T.G., 2nd; Kong, D.; Wang, Z.; Ali, S.; Philip, P.A.; Sarkar, F.H. Up-regulation of miR-200 and let-7 by natural agents leads to the reversal of epithelial-to-mesenchymal transition in gemcitabine-resistant pancreatic cancer cells. Cancer Res. 2009, 69, 6704-6712. [CrossRef] [PubMed]

151. Lu, Y.; Lu, J.; Li, X.; Zhu, H.; Fan, X.; Zhu, S.; Wang, Y.; Guo, Q.; Wang, L.; Huang, Y.; et al. MiR-200a inhibits epithelial-mesenchymal transition of pancreatic cancer stem cell. BMC Cancer 2014, 14, 85. [CrossRef] [PubMed]

152. Soubani, O.; Ali, A.S.; Logna, F.; Ali, S.; Philip, P.A.; Sarkar, F.H. Re-expression of miR-200 by novel approaches regulates the expression of pten and mt1-mmp in pancreatic cancer. Carcinogenesis 2012, 33, 1563-1571. [CrossRef] [PubMed]

153. Wellner, U.; Brabletz, T.; Keck, T. Zeb1 in pancreatic cancer. Cancers 2010, 2, 1617-1628. [CrossRef] [PubMed]

154. Berx, G.; Raspe, E.; Christofori, G.; Thiery, J.P.; Sleeman, J.P. Pre-emting metastasis? Recapitulation of morphogenetic processes in cancer. Clin. Exp. Metastasis 2007, 24, 587-597. [CrossRef] [PubMed]

155. Spaderna, S.; Schmalhofer, O.; Hlubek, F.; Berx, G.; Eger, A.; Merkel, S.; Jung, A.; Kirchner, T.; Brabletz, T. A transient, emt-linked loss of basement membranes indicates metastasis and poor survival in colorectal cancer. Gastroenterology 2006, 131, 830-840. [CrossRef] [PubMed]

156. Tavazoie, S.F.; Alarcon, C.; Oskarsson, T.; Padua, D.; Wang, Q.; Bos, P.D.; Gerald, W.L.; Massague, J. Endogenous human microRNAs that suppress breast cancer metastasis. Nature 2008, 451, 147-152. [CrossRef] [PubMed]

157. Bracken, C.P.; Gregory, P.A.; Kolesnikoff, N.; Bert, A.G.; Wang, J.; Shannon, M.F.; Goodall, G.J. A double-negative feedback loop between zeb1-sip1 and the microRNA-200 family regulates epithelial-mesenchymal transition. Cancer Res. 2008, 68, 7846-7854. [CrossRef] [PubMed] 
158. Burk, U.; Schubert, J.; Wellner, U.; Schmalhofer, O.; Vincan, E.; Spaderna, S.; Brabletz, T. A reciprocal repression between zeb1 and members of the miR-200 family promotes emt and invasion in cancer cells. EMBO Rep. 2008, 9, 582-589. [CrossRef] [PubMed]

159. Gregory, P.A.; Bert, A.G.; Paterson, E.L.; Barry, S.C.; Tsykin, A.; Farshid, G.; Vadas, M.A.; Khew-Goodall, Y.; Goodall, G.J. The miR-200 family and miR-205 regulate epithelial to mesenchymal transition by targeting zeb1 and sip1. Nat. Cell Biol. 2008, 10, 593-601. [CrossRef] [PubMed]

160. Hugo, H.J.; Pereira, L.; Suryadinata, R.; Drabsch, Y.; Gonda, T.J.; Gunasinghe, N.P.; Pinto, C.; Soo, E.T.; van Denderen, B.J.; Hill, P.; et al. Direct repression of myb by zeb1 suppresses proliferation and epithelial gene expression during epithelial-to-mesenchymal transition of breast cancer cells. Breast Cancer Res. 2013, 15, R113. [CrossRef] [PubMed]

161. Banyard, J.; Chung, I.; Wilson, A.M.; Vetter, G.; Le Bechec, A.; Bielenberg, D.R.; Zetter, B.R. Regulation of epithelial plasticity by miR-424 and miR-200 in a new prostate cancer metastasis model. Sci. Rep. 2013, 3, 3151. [CrossRef] [PubMed]

162. Choi, Y.C.; Yoon, S.; Jeong, Y.; Yoon, J.; Baek, K. Regulation of vascular endothelial growth factor signaling by miR-200b. Mol. Cells 2011, 32, 77-82. [CrossRef] [PubMed]

163. Cong, N.; Du, P.; Zhang, A.; Shen, F.; Su, J.; Pu, P.; Wang, T.; Zjang, J.; Kang, C.; Zhang, Q. Downregulated microRNA-200a promotes emt and tumor growth through the wnt/ $\beta$-catenin pathway by targeting the e-cadherin repressors zeb1/zeb2 in gastric adenocarcinoma. Oncol. Rep. 2013, 29, 1579-1587. [PubMed]

164. Roybal, J.D.; Zang, Y.; Ahn, Y.H.; Yang, Y.; Gibbons, D.L.; Baird, B.N.; Alvarez, C.; Thilaganathan, N.; Liu, D.D.; Saintigny, P.; et al. MiR-200 inhibits lung adenocarcinoma cell invasion and metastasis by targeting flt1/vegfr1. Mol. Cancer Res. 2011, 9, 25-35. [CrossRef] [PubMed]

165. Saydam, O.; Shen, Y.; Wurdinger, T.; Senol, O.; Boke, E.; James, M.F.; Tannous, B.A.; Stemmer-Rachamimov, A.O.; Yi, M.; Stephens, R.M.; et al. Downregulated microRNA-200a in meningiomas promotes tumor growth by reducing e-cadherin and activating the wnt/ $\beta$-catenin signaling pathway. Mol. Cell. Biol. 2009, 29, 5923-5940. [CrossRef] [PubMed]

166. Hicklin, D.J.; Ellis, L.M. Role of the vascular endothelial growth factor pathway in tumor growth and angiogenesis. J. Clin. Oncol. 2005, 23, 1011-1027. [CrossRef] [PubMed]

167. Ma, J.; Sawai, H.; Ochi, N.; Matsuo, Y.; Xu, D.; Yasuda, A.; Takahashi, H.; Wakasugi, T.; Takeyama, H. Pten regulates angiogenesis through PI3K/Akt/VEGF signaling pathway in human pancreatic cancer cells. Mol. Cell. Biochem. 2009, 331, 161-171. [CrossRef] [PubMed]

168. Ottaviano, A.J.; Sun, L.; Ananthanarayanan, V.; Munshi, H.G. Extracellular matrix-mediated membrane-type 1 matrix metalloproteinase expression in pancreatic ductal cells is regulated by transforming growth factor- $\beta 1$. Cancer Res. 2006, 66, 7032-7040. [CrossRef] [PubMed]

169. Li, C.; Heidt, D.G.; Dalerba, P.; Burant, C.F.; Zhang, L.; Adsay, V.; Wicha, M.; Clarke, M.F.; Simeone, D.M. Identification of pancreatic cancer stem cells. Cancer Res. 2007, 67, 1030-1037. [CrossRef] [PubMed]

170. Hermann, P.C.; Huber, S.L.; Herrler, T.; Aicher, A.; Ellwart, J.W.; Guba, M.; Bruns, C.J.; Heeschen, C. Distinct populations of cancer stem cells determine tumor growth and metastatic activity in human pancreatic cancer. Cell Stem Cell 2007, 1, 313-323. [CrossRef] [PubMed]

171. Kim, M.P.; Fleming, J.B.; Wang, H.; Abbruzzese, J.L.; Choi, W.; Kopetz, S.; McConkey, D.J.; Evans, D.B.; Gallick, G.E. ALDH activity selectively defines an enhanced tumor-initiating cell population relative to CD133 expression in human pancreatic adenocarcinoma. PLoS ONE 2011, 6, e20636. [CrossRef] [PubMed]

172. Olempska, M.; Eisenach, P.A.; Ammerpohl, O.; Ungefroren, H.; Fandrich, F.; Kalthoff, H. Detection of tumor stem cell markers in pancreatic carcinoma cell lines. Hepatobiliary Pancreat. Dis. Int. 2007, 6, 92-97. [PubMed]

173. Ahmad, A.; Maitah, M.Y.; Ginnebaugh, K.R.; Li, Y.; Bao, B.; Gadgeel, S.M.; Sarkar, F.H. Inhibition of hedgehog signaling sensitizes NSCLC cells to standard therapies through modulation of emt-regulating mirnas. J. Hematol. Oncol. 2013, 6, 77. [CrossRef] [PubMed]

174. Huang, H.N.; Chen, S.Y.; Hwang, S.M.; Yu, C.C.; Su, M.W.; Mai, W.; Wang, H.W.; Cheng, W.C.; Schuyler, S.C.; Ma, N.; et al. MiR-200c and gata binding protein 4 regulate human embryonic stem cell renewal and differentiation. Stem Cell Res. 2014, 12, 338-353. [CrossRef] [PubMed]

175. Shimono, Y.; Zabala, M.; Cho, R.W.; Lobo, N.; Dalerba, P.; Qian, D.; Diehn, M.; Liu, H.; Panula, S.P.; Chiao, E.; et al. Downregulation of miRNA-200c links breast cancer stem cells with normal stem cells. Cell 2009, 138, 592-603. [CrossRef] [PubMed] 
176. Hagman, Z.; Larne, O.; Edsjo, A.; Bjartell, A.; Ehrnstrom, R.A.; Ulmert, D.; Lilja, H.; Ceder, Y. MiR-34c is downregulated in prostate cancer and exerts tumor suppressive functions. Int. J. Cancer 2010, 127, 2768-2776. [CrossRef] [PubMed]

177. Ji, Q.; Hao, X.; Meng, Y.; Zhang, M.; Desano, J.; Fan, D.; Xu, L. Restoration of tumor suppressor miR-34 inhibits human p53-mutant gastric cancer tumorspheres. BMC Cancer 2008, 8, 266. [CrossRef] [PubMed]

178. Kalimutho, M.; Minutolo, A.; Grelli, S.; Formosa, A.; Sancesario, G.; Valentini, A.; Federici, G.; Bernardini, S. Satraplatin (jm-216) mediates $\mathrm{g} 2 / \mathrm{m}$ cell cycle arrest and potentiates apoptosis via multiple death pathways in colorectal cancer cells thus overcoming platinum chemo-resistance. Cancer Chemother. Pharmacol. 2011, 67, 1299-1312. [CrossRef] [PubMed]

179. Li, L.; Yuan, L.; Luo, J.; Gao, J.; Guo, J.; Xie, X. MiR-34a inhibits proliferation and migration of breast cancer through down-regulation of bcl-2 and sirt1. Clin. Exp. Med. 2013, 13, 109-117. [CrossRef] [PubMed]

180. Yang, S.; Li, Y.; Gao, J.; Zhang, T.; Li, S.; Luo, A.; Chen, H.; Ding, F.; Wang, X.; Liu, Z. MicroRNA-34 suppresses breast cancer invasion and metastasis by directly targeting FRA-1. Oncogene 2013, 32, 4294-4303. [CrossRef] [PubMed]

181. Misso, G.; Di Martino, M.T.; De Rosa, G.; Farooqi, A.A.; Lombardi, A.; Campani, V.; Zarone, M.R.; Gulla, A.; Tagliaferri, P.; Tassone, P.; et al. MiR-34: A new weapon against cancer? Mol. Ther. Nucleic Acids 2014, 3, e194. [CrossRef] [PubMed]

182. He, H.; Jazdzewski, K.; Li, W.; Liyanarachchi, S.; Nagy, R.; Volinia, S.; Calin, G.A.; Liu, C.G.; Franssila, K.; Suster, S.; et al. The role of microRNA genes in papillary thyroid carcinoma. Proc. Natl. Acad. Sci. USA 2005, 102, 19075-19080. [CrossRef] [PubMed]

183. Pacifico, F.; Crescenzi, E.; Mellone, S.; Iannetti, A.; Porrino, N.; Liguoro, D.; Moscato, F.; Grieco, M.; Formisano, S.; Leonardi, A. Nuclear factor- $k b$ contributes to anaplastic thyroid carcinomas through up-regulation of miR-146a. J. Clin. Endocrinol. Metab. 2010, 95, 1421-1430. [CrossRef] [PubMed]

184. Xu, L.; Zhong, H.; Wan, H.; Chen, F.Y.; Zhong, J.; Xiao, F.; Liu, J.; Shen, L. MiR-146a expression level as a novel putative prognostic marker for acute promyelocytic leukemia. Dis. Markers 2014, 2014, 150604. [CrossRef] [PubMed]

185. Wang, X.; Tang, S.; Le, S.Y.; Lu, R.; Rader, J.S.; Meyers, C.; Zheng, Z.M. Aberrant expression of oncogenic and tumor-suppressive microRNAs in cervical cancer is required for cancer cell growth. PLoS ONE 2008, 3, e2557. [CrossRef] [PubMed]

186. Lin, S.L.; Chiang, A.; Chang, D.; Ying, S.Y. Loss of miR-146a function in hormone-refractory prostate cancer. RNA 2008, 14, 417-424. [CrossRef] [PubMed]

187. Hou, Z.; Xie, L.; Yu, L.; Qian, X.; Liu, B. MicroRNA-146a is down-regulated in gastric cancer and regulates cell proliferation and apoptosis. Med. Oncol. 2012, 29, 886-892. [CrossRef] [PubMed]

188. Kogo, R.; Mimori, K.; Tanaka, F.; Komune, S.; Mori, M. Clinical significance of miR-146a in gastric cancer cases. Clin. Cancer Res. 2011, 17, 4277-4284. [CrossRef] [PubMed]

189. Bhaumik, D.; Scott, G.K.; Schokrpur, S.; Patil, C.K.; Campisi, J.; Benz, C.C. Expression of microRNA-146 suppresses NF- $\mathrm{kb}$ activity with reduction of metastatic potential in breast cancer cells. Oncogene 2008, 27, 5643-5647. [CrossRef] [PubMed]

190. Kumaraswamy, E.; Wendt, K.L.; Augustine, L.A.; Stecklein, S.R.; Sibala, E.C.; Li, D.; Gunewardena, S.; Jensen, R.A. Brca1 regulation of epidermal growth factor receptor (EGFR) expression in human breast cancer cells involves microRNA-146a and is critical for its tumor suppressor function. Oncogene 2014, 34, 4333-4346. [CrossRef] [PubMed]

191. Chen, G.; Umelo, I.A.; Lv, S.; Teugels, E.; Fostier, K.; Kronenberger, P.; Dewaele, A.; Sadones, J.; Geers, C.; De Greve, J. MiR-146a inhibits cell growth, cell migration and induces apoptosis in non-small cell lung cancer cells. PLoS ONE 2013, 8, e60317. [CrossRef] [PubMed]

192. Ali, S.; Ahmad, A.; Aboukameel, A.; Ahmed, A.; Bao, B.; Banerjee, S.; Philip, P.A.; Sarkar, F.H. Deregulation of miR-146a expression in a mouse model of pancreatic cancer affecting egfr signaling. Cancer Lett. 2014, 351, 134-142. [CrossRef] [PubMed]

193. Liang, Y.J.; Wang, Q.Y.; Zhou, C.X.; Yin, Q.Q.; He, M.; Yu, X.T.; Cao, D.X.; Chen, G.Q.; He, J.R.; Zhao, Q. MiR-124 targets slug to regulate epithelial-mesenchymal transition and metastasis of breast cancer. Carcinogenesis 2013, 34, 713-722. [CrossRef] [PubMed]

194. Lu, S.H.; Jiang, X.J.; Xiao, G.L.; Liu, D.Y.; Yuan, X.R. MiR-124a restoration inhibits glioma cell proliferation and invasion by suppressing iqgap1 and $\beta$-catenin. Oncol. Rep. 2014, 32, 2104-2110. [CrossRef] [PubMed] 
195. Peng, X.H.; Huang, H.R.; Lu, J.; Liu, X.; Zhao, F.P.; Zhang, B.; Lin, S.X.; Wang, L.; Chen, H.H.; Xu, X.; et al. MiR-124 suppresses tumor growth and metastasis by targeting foxq1 in nasopharyngeal carcinoma. Mol. Cancer 2014, 13, 186. [CrossRef] [PubMed]

196. Zhang, T.; Wang, J.; Zhai, X.; Li, H.; Li, C.; Chang, J. MiR-124 retards bladder cancer growth by directly targeting CDK4. Acta Biochim. Biophys. Sin. 2014, 46, 1072-1079. [CrossRef] [PubMed]

197. Agirre, X.; Vilas-Zornoza, A.; Jimenez-Velasco, A.; Martin-Subero, J.I.; Cordeu, L.; Garate, L.; San Jose-Eneriz, E.; Abizanda, G.; Rodriguez-Otero, P.; Fortes, P.; et al. Epigenetic silencing of the tumor suppressor microRNA hsa-miR-124a regulates CDK6 expression and confers a poor prognosis in acute lymphoblastic leukemia. Cancer Res. 2009, 69, 4443-4453. [CrossRef] [PubMed]

198. Lujambio, A.; Ropero, S.; Ballestar, E.; Fraga, M.F.; Cerrato, C.; Setien, F.; Casado, S.; Suarez-Gauthier, A.; Sanchez-Cespedes, M.; Git, A.; et al. Genetic unmasking of an epigenetically silenced microRNA in human cancer cells. Cancer Res. 2007, 67, 1424-1429. [CrossRef] [PubMed]

199. Das, E.; Jana, N.R.; Bhattacharyya, N.P. MicroRNA-124 targets CCNA2 and regulates cell cycle in STHdh(Q111)/Hdh(Q111) cells. Biochem. Biophys. Res. Commun. 2013, 437, 217-224. [CrossRef] [PubMed]

200. Baroukh, N.; Ravier, M.A.; Loder, M.K.; Hill, E.V.; Bounacer, A.; Scharfmann, R.; Rutter, G.A.; Van Obberghen, E. MicroRNA-124a regulates foxa2 expression and intracellular signaling in pancreatic beta-cell lines. J. Biol. Chem. 2007, 282, 19575-19588. [CrossRef] [PubMed]

201. Asuthkar, S.; Stepanova, V.; Lebedeva, T.; Holterman, A.L.; Estes, N.; Cines, D.B.; Rao, J.S.; Gondi, C.S. Multifunctional roles of urokinase plasminogen activator (upa) in cancer stemness and chemoresistance of pancreatic cancer. Mol. Biol. Cell 2013, 24, 2620-2632. [CrossRef] [PubMed]

202. Ikenaga, N.; Ohuchida, K.; Mizumoto, K.; Yu, J.; Kayashima, T.; Sakai, H.; Fujita, H.; Nakata, K.; Tanaka, M. MicroRNA-203 expression as a new prognostic marker of pancreatic adenocarcinoma. Ann. Surg. Oncol. 2010, 17, 3120-3128. [CrossRef] [PubMed]

203. Xu, D.; Wang, Q.; An, Y.; Xu, L. MiR203 regulates the proliferation, apoptosis and cell cycle progression of pancreatic cancer cells by targeting survivin. Mol. Med. Rep. 2013, 8, 379-384. [PubMed]

204. Chitkara, D.; Mittal, A.; Mahato, R.I. MiRNAs in pancreatic cancer: Therapeutic potential, delivery challenges and strategies. Adv. Drug Deliv. Rev. 2015, 81, 34-52. [CrossRef] [PubMed]

205. Naidu, S.; Magee, P.; Garofalo, M. MiRNA-based therapeutic intervention of cancer. J. Hematol. Oncol. 2015, 8, 68. [CrossRef] [PubMed]

206. Rothschild, S.I. MicroRNA therapies in cancer. Mol. Cell. Ther. 2014, 2, 7. [CrossRef] [PubMed]

207. Li, W.; Zang, W.; Liu, P.; Wang, Y.; Du, Y.; Chen, X.; Deng, M.; Sun, W.; Wang, L.; Zhao, G.; et al. MicroRNA-124 inhibits cellular proliferation and invasion by targeting ets-1 in breast cancer. Tumour Biol. 2014, 35, 10897-10904. [CrossRef] [PubMed]

208. Pramanik, D.; Campbell, N.R.; Karikari, C.; Chivukula, R.; Kent, O.A.; Mendell, J.T.; Maitra, A. Restitution of tumor suppressor microRNAs using a systemic nanovector inhibits pancreatic cancer growth in mice. Mol. Cancer Ther. 2011, 10, 1470-1480. [CrossRef] [PubMed]

209. Soifer, H.S.; Rossi, J.J.; Saetrom, P. MicroRNAs in disease and potential therapeutic applications. Mol. Ther. 2007, 15, 2070-2079. [CrossRef] [PubMed]

210. Vychytilova-Faltejskova, P.; Kiss, I.; Klusova, S.; Hlavsa, J.; Prochazka, V.; Kala, Z.; Mazanec, J.; Hausnerova, J.; Kren, L.; Hermanova, M.; et al. MiR-21, miR-34a, miR-198 and miR-217 as diagnostic and prognostic biomarkers for chronic pancreatitis and pancreatic ductal adenocarcinoma. Diagn. Pathol. 2015, 10, 38. [CrossRef] [PubMed]

211. Sicard, F.; Gayral, M.; Lulka, H.; Buscail, L.; Cordelier, P. Targeting miR-21 for the therapy of pancreatic cancer. Mol. Ther. 2013, 21, 986-994. [CrossRef] [PubMed]

212. Van Rooij, E.; Purcell, A.L.; Levin, A.A. Developing microRNA therapeutics. Circ. Res. 2012, 110, $496-507$. [CrossRef] [PubMed]

(C) 2016 by the authors; licensee MDPI, Basel, Switzerland. This article is an open access article distributed under the terms and conditions of the Creative Commons Attribution (CC-BY) license (http:/ / creativecommons.org/licenses/by/4.0/). 